\title{
Ca-rich garnets and associated symplectites in mafic peraluminous granulites from the Gföhl Nappe System, Austria
}

\author{
Konstantin Petrakakis ${ }^{1}$, Nathalie Schuster-Bourgin ${ }^{2}$ Gerlinde Habler $^{2}$, and Rainer Abart ${ }^{2}$ \\ ${ }^{1}$ Department of Geodynamics and Sedimentology, University of Vienna, Vienna, Austria \\ ${ }^{2}$ Department of Lithospheric Research, University of Vienna, Vienna, Austria
}

Correspondence: Konstantin Petrakakis (konstantin.petrakakis@univie.ac.at)

Received: 5 March 2018 - Discussion started: 12 March 2018

Revised: 17 May 2018 - Accepted: 18 May 2018 - Published: 19 June 2018

\begin{abstract}
Mafic peraluminous granulites associated with the mantle-derived peridotites of the Dunkelsteiner Wald provide evidence of the tectono-metamorphic evolution of the Gföhl Nappe System, Austria. They contain the primary assemblage garnet + Al-rich clinopyroxene + kyanite. Large $\mathrm{Ca}-$ and $\mathrm{Mg}$-rich garnets are embedded in a granoblastic matrix of Al-rich clinopyroxene, Ca-rich plagioclase and minor hornblende. They were partially replaced by different generations of symplectites: (a) corundum + sapphirine + spinel + plagioclase formed around kyanite inclusions, (b) orthopyroxene + spinel + plagioclase \pm hornblende formed at their rims and (c) clinopyroxene + orthopyroxene + spinel + plagioclase \pm hornblende formed within cracks.

Large garnets show complex compositional structure comprising several repeatedly occurring garnet types, which are characterized by specific compositions. The areal extent and the cross-cutting relations observed in element distribution maps allowed for the derivation of the relative timing of the formation of the different garnet types. The compositional features of the garnets indicate post-formational modification by intra-crystalline diffusion and metasomatic agents.

The garnet composition isopleths in equilibrium assemblage diagrams are in line with compositions modification as indicated by the element distribution maps. They confirm the deviation of composition from equilibrium for all garnet types. Furthermore, at least the youngest garnet types show evidence of metasomatic $(\mathrm{Fe}+\mathrm{Mg})$ loss affecting their $\mathrm{Ca}$ content. Pressure-temperature $(P-T)$ estimates are based on equilibrium assemblage diagrams that reproduce satisfactorily the observed mineral assemblages and measured mineral compositions. Criteria for checking the existence of preserved equilibrium compositions are suggested. The results
\end{abstract}

call into question the invariability of the assumption that the Ca content and/or zoning in garnet preserves primary $P-T$ information from garnet growth in every case.

Recrystallization and compositional readjustment of the reactive garnet volume during symplectite formation led to the development of pronounced, secondary diffusioninduced zoning profiles overprinting the different garnet types and post-dating the complex garnet compositional structure. The primary assemblage is stable between 760 and $880^{\circ} \mathrm{C}$ and pressures $>11 \mathrm{kbar}$. The bulk composition of the crack symplectites is almost isochemical to the oldest, broken-down garnet type. These symplectites were formed above $730^{\circ} \mathrm{C}$ and pressures between 5 and $7.5 \mathrm{kbar}$. The rocks studied underwent more or less isothermal decompression from pressures above 11 to $\sim 6 \mathrm{kbar}$ at temperatures of about $800^{\circ} \mathrm{C}$. Crack and rim symplectites were formed after decompression during the early stage of approximately isobaric cooling under conditions of low differential stress. Due to limited availability of fluids promoting symplectite formation, the timescale of symplectite formation calculated from secondary diffusion profiles associated with crack symplectites is shown to be geologically very short $(<0.5 \mathrm{ka})$.

\section{Introduction}

Reconstruction of the pressure-temperature $(P-T)$ conditions attained by metamorphic rocks during their evolution provides key information for the assessment of geodynamics of orogenic belts. Reconstructions of the $P-T$ history of metamorphic rocks are based on the thermodynamic analysis of equilibrium-phase relations. Thereby, preservation of equi- 
librium is often difficult to assess and often is tacitly assumed rather than rigorously tested.. Especially in rocks metamorphosed under granulite facies conditions, the equilibriumphase relations attained at peak metamorphic conditions may be modified in the course of slow cooling, or due to recrystallization, repeated deformation and retrogression.

Due to its refractory nature, garnet is considered to be one of the minerals which most reliably preserves its original composition. Based on its low inter-diffusion coefficient, $\mathrm{Ca}$ in garnet is supposed to be particularly robust and hardly affected by late recrystallization and retrogression. With this study, we challenge this proposition by analyzing granulite facies rocks from the eastern-most part of the Moldanubian Zone of the Variscan orogen exposed in the Czech Republic and in Austria (see Fig. 1).

Over approximately the last 3 decades, the assessment of the $P-T$ evolution of granulites and associated rocks within the Moldanubian high-grade Gföhl Nappe System has been addressed by dozens of papers. The high number alone points to a poor agreement of the estimated $P-T$ conditions and $P_{-}$ $T$ path interpretations. Table 1 is a representative selection of the most recent $P-T$ estimates complemented with the obvious resulting geodynamic implications.

The $P-T$ estimates in Table 1 are based on three approaches. The first approach used conventional continuousreaction thermobarometry involving integral ternary feldspar compositions from perthite and antiperthite, Na-bearing clinopyroxene and the $\mathrm{Ca}$ content in garnet (O'Brien, 2008; Vrána et al., 2013, and references therein). The calculated $P$ $T$ conditions are about $1000^{\circ} \mathrm{C}$ and pressure of $15-20 \mathrm{kbar}$, occasionally more. The second approach additionally provides the derivation of the prograde path of the rocks with the aid of equilibrium assemblage diagrams (pseudo-sections) mostly combined with results of conventional geothermobarometry relying again on garnet Ca content (Štípská and Powell, 2005a; Racek et al., 2008; Štípská et al., 2014a; Jedlička et al., 2015; Jedlička and Faryad, 2017). This approach implies the most complex geodynamic evolution of the rocks (see Table 1). The third approach aims similarly at the derivation of $P-T$ paths, but points also to anatectic and open-system processes that have affected rocks and minerals under the specific "Moldanubian" conditions (Hasalová et al., 2008b; Śtípská et al., 2014a).

The most probable reason for the observed divergence of $P-T$ estimates is that in such rocks partial or complete readjustment of rock microstructures, mineral abundances and compositions during their multi-stage tectono-metamorphic evolution may hinder the calculation of consistent $P-T$ estimates. Critical discussions about the deviation of minerals from equilibrium composition are, indeed, found in most of the papers given in Table 1. The discussions deal with (i) the diffusion-aided $\mathrm{Na}$ loss in clinopyroxene during the granulite facies overprint, (ii) the effects of decompression and rock recrystallization and (iii) the available thermodynamic properties of minerals and their validity for thermo- barometric calculations. However, and irrespective of thermodynamic method used, all $P-T$ estimates listed in Table 1 are based explicitly or implicitly on the assumption that garnets, and especially their Ca contents, were hardly affected by processes other than changes of $P-T$ and that, therefore, any observed $\mathrm{Ca}$ zoning preserved past $P-T$ information.

In this paper, we address Ca-rich garnets (see Table 2) and associated symplectites in mafic, garnet-clinopyroxenekyanite granulites that call into question the invariability of the above assumption. Extensive microprobe analysis and element mapping showed that the garnet composition, in particular the Ca content, was modified by intra-crystalline diffusion and metasomatizing agents. Extending the possibilities currently offered by the calculation of equilibrium assemblage diagrams, we present criteria for the evaluation of preserved equilibrium compositions by checking the behavior of phase component isopleths. We emphasize the reliability of $P-T$ estimates derived from equilibrium assemblage diagrams in the case they satisfactorily reproduce the observed assemblages and mineral compositions. We have resolved the late evolution of the Moldanubian samples at hand with particular reference to garnet behavior. Garnet composition modification predated a largely isothermal decompression of the rocks that started above $11 \mathrm{kbar}$ at a temperature of $\sim 800^{\circ} \mathrm{C}$. This decompression induced garnet breakdown and compositional re-adjustment and recrystallization of reactive garnet volumes associated with the formation of different, locally controlled symplectites within a very short time interval during early, post-decompression, $\mathrm{H}_{2} \mathrm{O}-$ undersaturated conditions that were characterized by strainfree, almost isobaric cooling at $\sim 6 \mathrm{kbar}$.

\section{Methods of data acquisition and recalculation}

Extensive description of the methods of data acquisition and recalculation (rock and mineral analyses) and of symplectite modal analysis, bulk composition calculation of crack symplectites and electron backscatter diffraction (EBSD) analysis of crack symplectites are given in the Supplement. Tables of averaged microprobe analyses of the minerals with standard deviations of the measured oxides are given.

The notation used throughout the text is as follows: SOLID SOLUTION; phase_component; Pure_phase. Mineral and component abbreviations are as follows:

- CPX: clinopyroxene $d i, h d, c T s, j d$ [diopside, hedenbergite, calcium Tschermak's pyroxene, jadeite];

- GRT: garnet; alm, sps, prp, grs [almandine, spessartite, pyrope, grossularite];

- HBL: hornblende; $X_{\mathrm{mg}}[\mathrm{Mg} /(\mathrm{Mg}+\mathrm{Fe})]$;

- OL: olivine; $f o, f a$ [forsterite, fayalite];

- OPX: orthopyroxene; en, $f s$ [enstatite, ferrosilite]; 


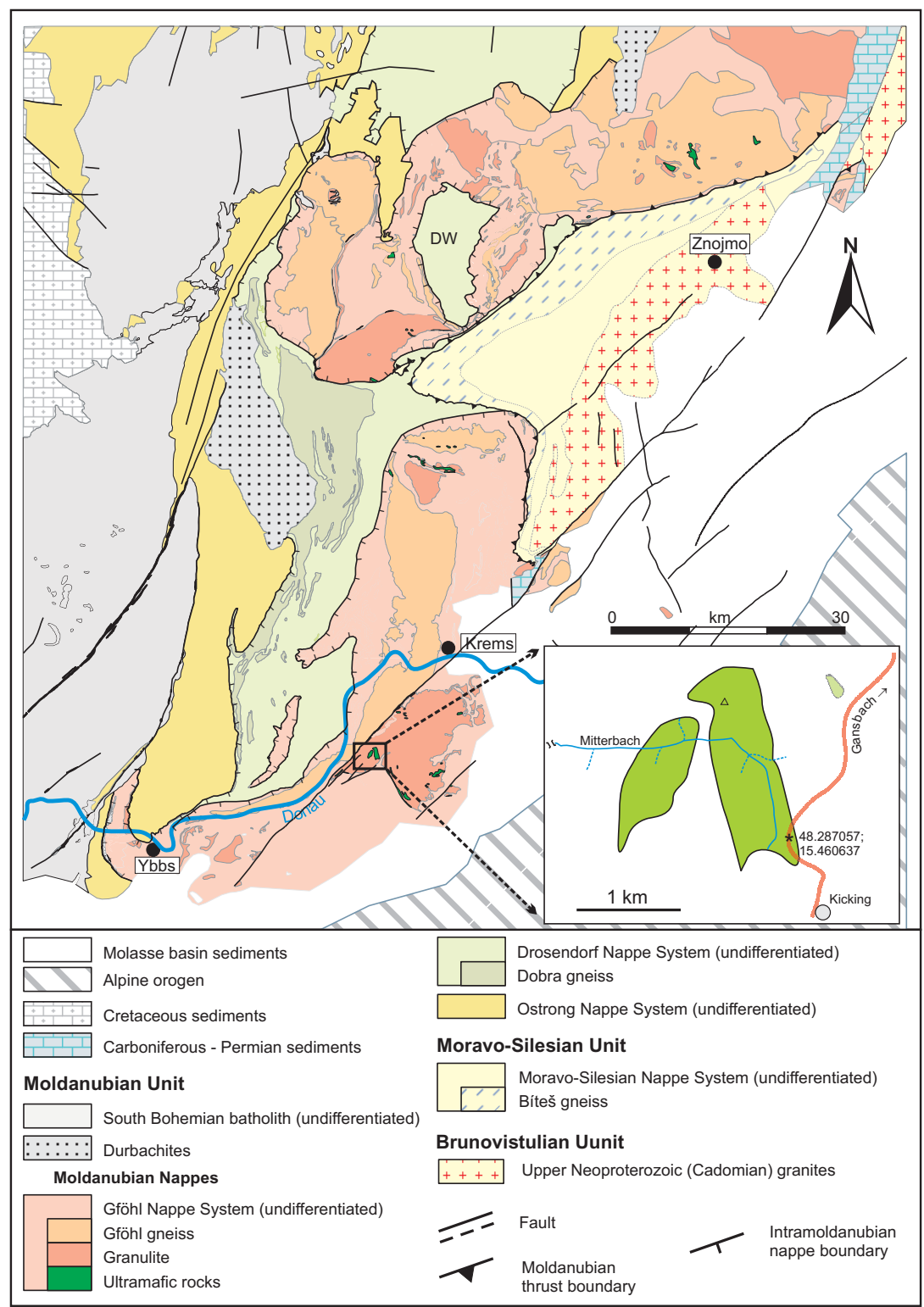

Figure 1. Simplified geological map of the Austrian part of the Moldanubian Unit modified after Schnabel (2002), Krenmayr et al. (2006), Cháb et al. (2007) and Kalvoda et al. (2008). DW signifies the Drosendorf Window. The inset is a sketch of the sampling area of the mafic granulites (embedded within felsic granulites) at the steep flanks of Mitterbachgraben. The Gansbach-Kicking road and the GPS coordinates at the star are shown (after Sheet 37, "Mautern", Geological Survey of Austria).

- ILM: ilmenite; $X_{\mathrm{mg}}[\mathrm{Mg} /(\mathrm{Mg}+\mathrm{Fe})]$

- SPL: spinel; spl, hrc [spinel, hercynite];

- SPR: sapphirine; $X_{\mathrm{mg}}[\mathrm{Mg} /(\mathrm{Mg}+\mathrm{Fe})]$

- PL: plagioclase; $a n, a b$ [anorthite, albite];

- Crn: corundum; Ky: kyanite; Ms: white mica; Qtz: quartz; Prh: prehnite; Rt: rutile; Tnt: titanite;

- Additional normative components: crn: corundum; hy: hypersthene; ol: olivine.

\section{Geological background}

The Moldanubian Unit in Austria forms the eastern-most, belt-like part of the Variscan orogen with a general NNESSW strike. In its western part, it has been intruded by granitic rocks of the South Bohemian Pluton; in the east, it has been thrusted over rocks of the Moravo-Silesian Unit (Schulmann et al., 2008, Fig. 1). It is composed of three lithotectonic nappe systems that generally dip to the east. The Gföhl Nappe System takes the highest tectonic position with felsic mylonitic granulites occurring at its top. The granulites 
Table 1. Selection of proposed $P-T$ estimates complemented with obvious geodynamic implications from Moldanubian granulites and associated rocks in the Gföhl Nappe System, Moldanubian Unit. References: 1 - Štípská and Powell (2005a); 2 - Štípská and Powell (2005b); 3 - Racek et al. (2006); 4 - O’Brien (2008) and references therein; 5 - Racek et al. (2008); 6 - Faryad et al. (2010); 7 - Vrána et al. (2013) and references therein; 8 - Štípská et al. (2014a); 9 - Jedlička et al. (2015); 10 - Jedlička and Faryad (2017). ??? - not given.

\begin{tabular}{|c|c|c|c|c|c|c|}
\hline \multicolumn{5}{|c|}{$P($ kbar $) \& T\left({ }^{\circ} \mathrm{C}\right)$} & \multirow[t]{2}{*}{ Method } & \multirow[t]{2}{*}{ Ref. } \\
\hline Initial stage & Implications & Peak & Implications & Post-peak & & \\
\hline & & $18 \& 850$ & & & EAD & 1 \\
\hline \multirow{2}{*}{$\begin{array}{l}\text { Dry magmatic @ } \\
8-10 \&>1000\end{array}$} & $\rightarrow$ compression $\rightarrow$ & $<18 \&<850$ & $\rightarrow$ decompression $\rightarrow$ & $8-9 \& 800$ & EAD & 2 \\
\hline & & $15 \& 800$ & & & EAD & 3 \\
\hline \multirow[t]{2}{*}{$10 \& ? ? ?$} & & $15 \& ? ? ?$ & & $7-10 \& 750$ & & \\
\hline & & $15-22 \& \sim 1000$ & & & GTB & 4 \\
\hline \multirow[t]{3}{*}{$\begin{array}{l}\text { Magmatic@ } \\
14 \&>950\end{array}$} & $\rightarrow$ compression $\rightarrow$ & $\begin{array}{l}10-17 \& 650-850 \\
\text { or } 20 \& 770\end{array}$ & $\rightarrow$ decompression $\rightarrow$ & $5-7 \&<800$ & EAD & 5 \\
\hline & & $22 \& 900$ & $\rightarrow$ decompression $\rightarrow$ & $\begin{array}{l}16 \& 850 \text { or } \\
10 \& 870\end{array}$ & EAD & 6 \\
\hline & & $22-23 \& ? ? ?$ & & & GTB & 7 \\
\hline $\begin{array}{l}\text { Eclogite @ } \\
18 \& 900\end{array}$ & $\begin{array}{l}\rightarrow \text { decompression } \& \\
\text { metasomatism to } \\
\text { granulite } \rightarrow\end{array}$ & $12 \& 950$ & & & EAD+open-sys & 8 \\
\hline $6 \& 400$ & $\rightarrow$ prograde $P-T \rightarrow$ & $32-40 \& \sim 700$ & $\begin{array}{l}\rightarrow \text { decompression } \& \\
\text { re-heating } \rightarrow\end{array}$ & $15-20 \& 800-1000$ & EAD+open-sys & 9 \\
\hline $8-9 \& 460$ & $\rightarrow$ prograde $P-T \rightarrow$ & $24-25 \& 550$ & $\begin{array}{l}\rightarrow \text { decompression } \& \\
\text { re-heating } \rightarrow\end{array}$ & $16-18 \& 800-870$ & EAD & 10 \\
\hline
\end{tabular}

Method refers to $P-T$ calculation method used: EAD, equilibrium assemblage diagrams (pseudo-sections); EAD+open-sys, EAD with additional consideration of open system processes; GTB, conventional continuous one-reaction geothermobarometry. Ref. means reference.

Table 2. Composition and features of garnet types. $m(n)$ and \pm SD are the average and standard deviation of $n$ consecutive point analyses of uniform composition along the garnet profile Z1-Z2-Z3 in Fig. 5a; see also Supplement, Table S3 and Fig. S2.

\begin{tabular}{|c|c|c|c|c|c|c|c|c|c|c|c|}
\hline \multirow[t]{2}{*}{ GRT-type } & \multicolumn{2}{|c|}{$\mathrm{Z1}$} & \multicolumn{2}{|c|}{$\mathrm{Z} 2$} & \multicolumn{2}{|c|}{$\mathrm{C}$} & \multicolumn{2}{|c|}{$\mathrm{Z3}$} & \multicolumn{2}{|c|}{ E } & \multirow[t]{2}{*}{$\mathrm{Z} 3-\mathrm{C}$} \\
\hline & $m(50)$ & $\pm \mathrm{SD}$ & $m(36)$ & $\pm \mathrm{SD}$ & $m(32)$ & $\pm \mathrm{SD}$ & $m(21)$ & $\pm \mathrm{SD}$ & $m(18)$ & $\pm \mathrm{SD}$ & \\
\hline$X_{\text {alm }}$ & 0.23 & 0.00 & 0.24 & 0.00 & 0.26 & 0.00 & 0.19 & 0.00 & 0.18 & 0.00 & -0.07 \\
\hline$X_{\text {prp }}$ & 0.58 & 0.01 & 0.51 & 0.00 & 0.54 & 0.00 & 0.47 & 0.00 & 0.60 & 0.01 & -0.06 \\
\hline$X_{\mathrm{grs}}$ & 0.18 & 0.01 & 0.24 & 0.00 & 0.19 & 0.00 & 0.32 & 0.01 & 0.19 & 0.01 & 0.13 \\
\hline $\begin{array}{l}\text { Features } \\
\text { overview }\end{array}$ & $\begin{array}{c}\quad g r s< \\
\text { occurre }\end{array}$ & $\begin{array}{l}r p ; \\
\text { ype C }\end{array}$ & $\begin{array}{l}\text { Lowe } \\
\text { alm }\end{array}$ & $\begin{array}{l}\text { prp; } \\
\text { grs }\end{array}$ & $\begin{array}{c}\quad g r s< \\
\text { occurre }\end{array}$ & $\begin{array}{l}r p ; \\
\text { pe Z1 }\end{array}$ & $\begin{array}{l}\text { Highe } \\
\text { alm }<g\end{array}$ & $\begin{array}{l}\text { grs; } \\
<p r p\end{array}$ & $\begin{array}{r}\text { High } \\
\text { grs }\end{array}$ & $\begin{array}{l}\text { prp; } \\
\text { alm }\end{array}$ & \\
\hline
\end{tabular}

are intimately underlain by the widespread Gföhl Gneiss and subordinate amphibolites. Garnet peridotites with associated pyroxenites and eclogites represent tectonically emplaced fragments of the Earth's upper mantle (Medaris et al., 2005; Svojtka et al., 2016, and references therein) within the felsic granulites and rarely Gföhl Gneiss. The Drosendorf Nappe System (lithologically Bunte, or Variegated Series) lies below the Gföhl Nappe System. It is composed of amphibolites, marbles, gneisses and quartzites overlying the basal Dobra
Gneiss. It is also exposed within the Gföhl Nappe System in the Drosendorf Window (see Fig. 1). The tectonically lowest Ostrong Nappe System (lithologically Monotonous Series) is in contact with the South Bohemian Pluton. It is composed of migmatic, garnet-free cordierite gneiss with subordinate felsic gneiss and rare eclogitic bodies.

The metamorphic grade of the granulites within the Gföhl Nappe System has been addressed in the previous section. Hasalová et al. (2008a) studied the gneisses and migmatites 
of the Gföhl Nappe System showing structural transitions from banded orthogneiss to stromatic, schlieren and nebulitic migmatites formed by anatectic melt infiltration at conditions from $<850{ }^{\circ} \mathrm{C}$ and $7.5 \mathrm{kbar}$ to $690^{\circ} \mathrm{C}$ and $4.5 \mathrm{kbar}$. Anatexis is a widespread phenomenon within the Gföhl Nappe System affecting not only the Gföhl Gneiss but also the mylonitic felsic granulites and amphibolites. This is most evident in many outcrops along the Danube (Fig. 1). Anatectic conditions of $700-800^{\circ} \mathrm{C}$ at $\sim 8 \mathrm{kbar}$ and evidence for decompression has also been documented for the Drosendorf Nappe System (Petrakakis, 1997; Racek et al., 2006). The Ostrong Nappe System is similarly anatectic, but differs distinctly in terms of pressure from the other Moldanubian nappe systems (Linner, 1996). Based on rare relics of kyanite and staurolite, the rocks attained a prograde maximum at temperatures $<600^{\circ} \mathrm{C}$ and pressures of $\sim 6 \mathrm{kbar}$. Subsequent anatexis took place at $\sim 720^{\circ} \mathrm{C}$ and pressures not less than $4.5 \mathrm{kbar}$.

Seven samples of mafic granulites were collected from loose boulders dispersed over the steep flanks of the Mitterbachgraben (inset, Fig. 1). The local bedrock comprises serpentinites of the mantle-derived peridotite of the Dunkelsteiner Wald. The ultramafic rocks form several $100 \mathrm{~m}$ long lensoid bodies embedded in mylonitic felsic granulite. The collected samples are noticeable in the field, as they do not belong to the regionally widespread rock types in this area. They are dark gray, middle- to fine-grained, mostly granofelsic mafic granulites containing abundant pyroxene and kelyphitic reddish brown garnets of occasionally striking large size up to $1.5 \mathrm{~cm}$.

Previous work on similar rocks from the same area was presented by Carswell et al. (1989). They interpreted the protoliths of these silica undersaturated, Mg-rich rocks showing high normative plagioclase contents as cumulateliquid mixes of intra-plate basaltic magmas with lower crust rocks. According the these authors, the observed primary assemblage GRT + CPX + Ky was formed at $30 \mathrm{kbar}$ and $1146-1102^{\circ} \mathrm{C}$. They also ascribed the rarely observed SPR + PL symplectites, which were formed at the expense of Ky + GRT to conditions of $1000^{\circ} \mathrm{C}$ and $P<20 \mathrm{kbar}$. Finally, hornblende rimming matrix clinopyroxene was formed at amphibolite facies conditions.

$\mathrm{X}$-ray fluorescence (XRF) analyses of the samples collected for this study reveal $\mathrm{K}$-poor, Mg-rich compositions with $X_{\mathrm{mg}}$ ranging within $0.70-0.82$. Analyses of bulk rock composition and calculated normative contents are given in the Supplement. In terms of normative contents, they contain $\mathrm{crn}$ in the range 10 to $16 \%$. Three of them contain an in the range 9 to $19 \%$; the other four samples contain instead ol between 3 and $9 \%$. The di contents of all samples vary between 48 and $61 \%$ and the hy content between 3 and $19 \%$. The $a b$ content varies between 9 and $19 \%$. Some of the samples (UM5, UM6, UM8) resemble the corundumbearing garnet clinopyroxenites from the Beni Bousera ultramafic massif that are considered to be low-pressure crys- tallization cumulates from plagioclase-rich gabbros of ophiolitic affinity that underwent subduction and re-equilibration at mantle conditions (Kornprobst et al., 1990). Svojtka et al. (2016) assigned the Dunkelsteiner Wald pyroxenites occurring around the sampling area to light rare earth elementenriched melts of the subcontinental lithospheric mantle. In comparison with $\mathrm{Al}_{2} \mathrm{O}_{3}$ contents of $15-24$ wt. \% in the samples presented here, their pyroxenitic samples are characterized by significantly lower $\mathrm{Al}_{2} \mathrm{O}_{3}$ not exceeding $12.23 \mathrm{wt}$. \% and higher $X_{\mathrm{mg}}$ of $0.87-0.90$. Based on the pronounced peraluminous composition variability, we consider our samples to be mantle-derived clinopyroxenitic melts that have assimilated variable amounts of Al-rich crustal material during ascent and tectonic emplacement to their current position.

The collected samples are mineralogically similar containing slightly variable amounts of clinopyroxene, plagioclase and garnet accompanied by some hornblende. The following presentation and discussion is focused on sample UM8 that contains some large garnets with an unusual high number of features. This sample is the most magnesian and peraluminous of the whole collection $\left(X_{\mathrm{mg}}=0.82\right.$ with normative $c r n=14.07 \%$ and $a n=18.78 \%)$.

\section{Rock fabric and mineral assemblages}

The most abundant phase in the mafic granulite UM8 is clinopyroxene followed by plagioclase, fewer garnet of occasionally large size and still fewer brownish hornblende (Fig. 2a). The rock matrix is fine-grained with typical crystal sizes ranging from 0.1 to $0.3 \mathrm{~mm}$. Besides clinopyroxene and plagioclase, sporadic relics of garnet associated with orthopyroxene-bearing symplectitic intergrowths occur within the rock matrix (Fig. 2b). Hornblende is a common, but minor phase (see Fig. 2c). Fine-grained hornblende and white mica are abundant along the conspicuous darker, thin and straight bands that cross-cut the rock matrix (Fig. 2a).

Under the light polarizing microscope, the matrix is granoblastic, almost equigranular, comprising smooth to straight interfaces among clinopyroxene, plagioclase and hornblende that meet at triple junctions (Fig. 2c). The large, up to $1.3 \mathrm{~cm}$ sized garnets (Fig. 2a) are partially kelyphitized and contain kyanite and clinopyroxene inclusions (Fig. 2d). Plagioclase is often observed with clinopyroxene in the inclusion domains of garnet. Kyanite inclusions were partially to completely replaced by symplectites of plagioclase and tiny, highly refractive minerals (Fig. 2d). Granular green spinel can be occasionally recognized among them. In addition, these garnets exhibit $0.1-0.2 \mathrm{~mm}$ wide mode I (extensional) cracks, which are filled with fine-grained symplectite (Fig. 2e). Most garnets are however much smaller with sizes less than $4 \mathrm{~mm}$ (Fig. 2f). Such garnets are kelyphitized too, but kyanite inclusions are seldom. They typically contain only clinopyroxene and plagioclase in their inclusion domains. 

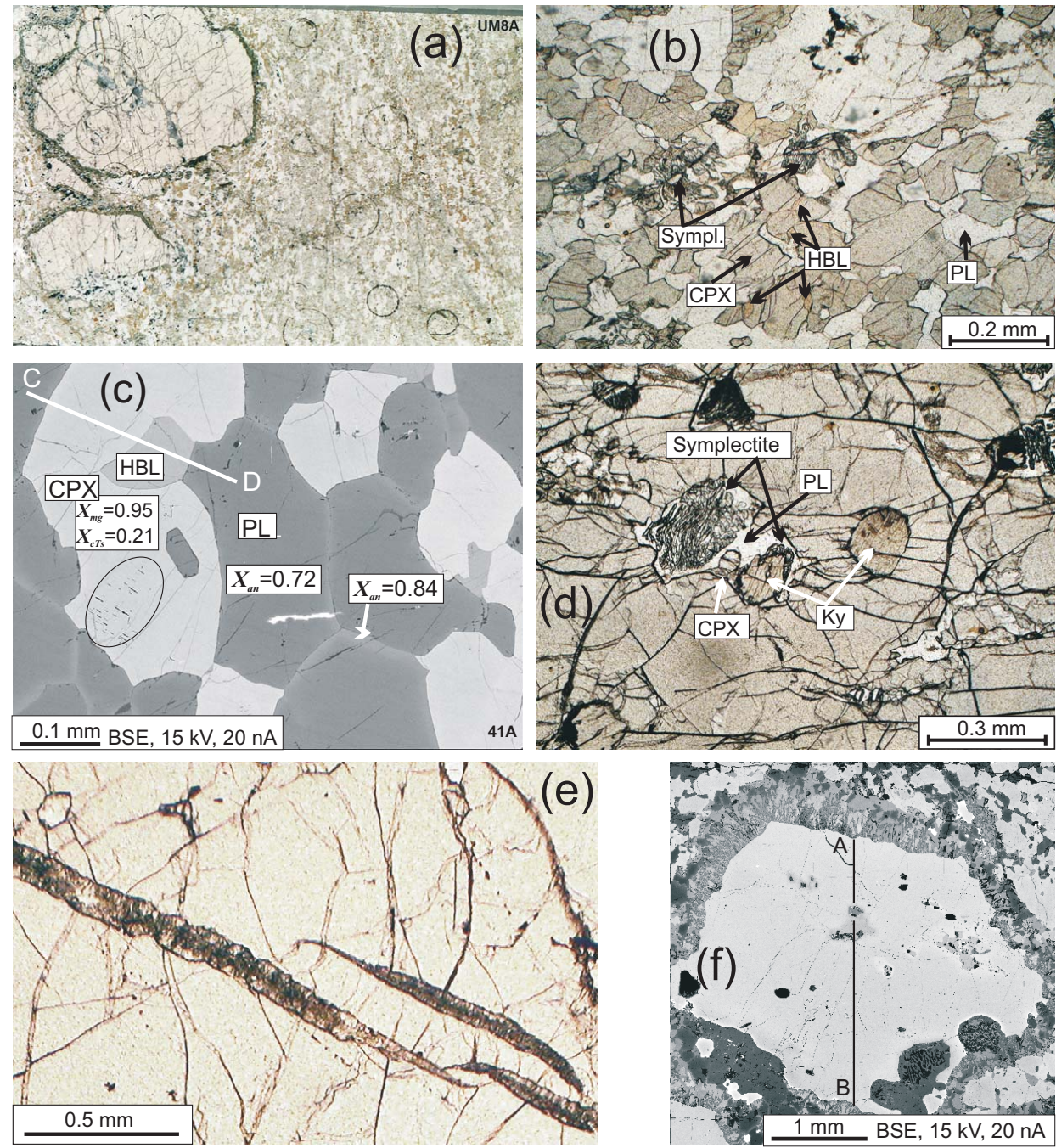

Figure 2. Rock and mineral features in sample UM8. Panels (a), (b), (d) and (e) are taken with a polarizing microscope. (a) Thin section showing one of the largest, partially kelyphitized garnets (diameter $\sim 1.3 \mathrm{~cm}$ ). The abundant gray crystals in the matrix are clinopyroxene with scarce garnet relics; white crystals are feldspar and the light brownish ones hornblende. The thin straight darker bands cross-cutting the rock matrix are rich in hornblende and white mica. The black cycles are orientation marks for microprobe analysis. (b) Granoblastic rock matrix showing clinopyroxene and plagioclase crystals with subordinate, small brownish crystals of hornblende. The small, irregular, highly refractive constituents (designated as Sympl.) are relics of garnet and symplectitic intergrowths containing orthopyroxene. (c) BSE image of the rock matrix showing smooth interfaces and triple junctions among clinopyroxene, plagioclase and hornblende as well as thin exsolution lamellas in the clinopyroxene interior shown with an ellipse. The plagioclase rims are enriched with Ca. The profile C-D is shown in Fig. 7b. (d) Kyanite and clinopyroxene inclusions in garnet partially or totally replaced by symplectite of plagioclase and highly refractive minerals. (e) $0.1-0.2 \mathrm{~mm}$ wide, mode I cracks in garnet filled with fine-grained symplectite. (f) BSE image of a middle-sized garnet showing an inclusion-related symplectite within the resorption garnet embayment and a kelyphite at rims.

The garnets of the rock were partially replaced by different symplectites. Based on their formation environment, three types of symplectites can be discerned:

- Symplectites around kyanite inclusions in garnet (Fig. 3). The primary assemblage GRT $+\mathrm{Ky}$ broke down, forming initially a coarse-grained symplectite of SPL + PL + Crn (Fig. 3a, b). Corundum intergrown with spinel is then overgrown and replaced partially by sapphirine (Fig. 3c). Finally, the initial SPL + PL + Crn symplectite was partially replaced by a fine-grained SPR + PL symplectite. Noticeably and as shown in Fig. 3d and e, the broken-down products corundum and sapphirine are intergrown with the retreating garnet edge. GRT + Ky breakdown has led elsewhere to the complete consumption of kyanite (Fig. 3f). The contrast-enhanced enlargement in Fig. 3g shows that sapphirine was also overgrown by spinel of an extremely fine-grained OPX + SPL symplectite. This 

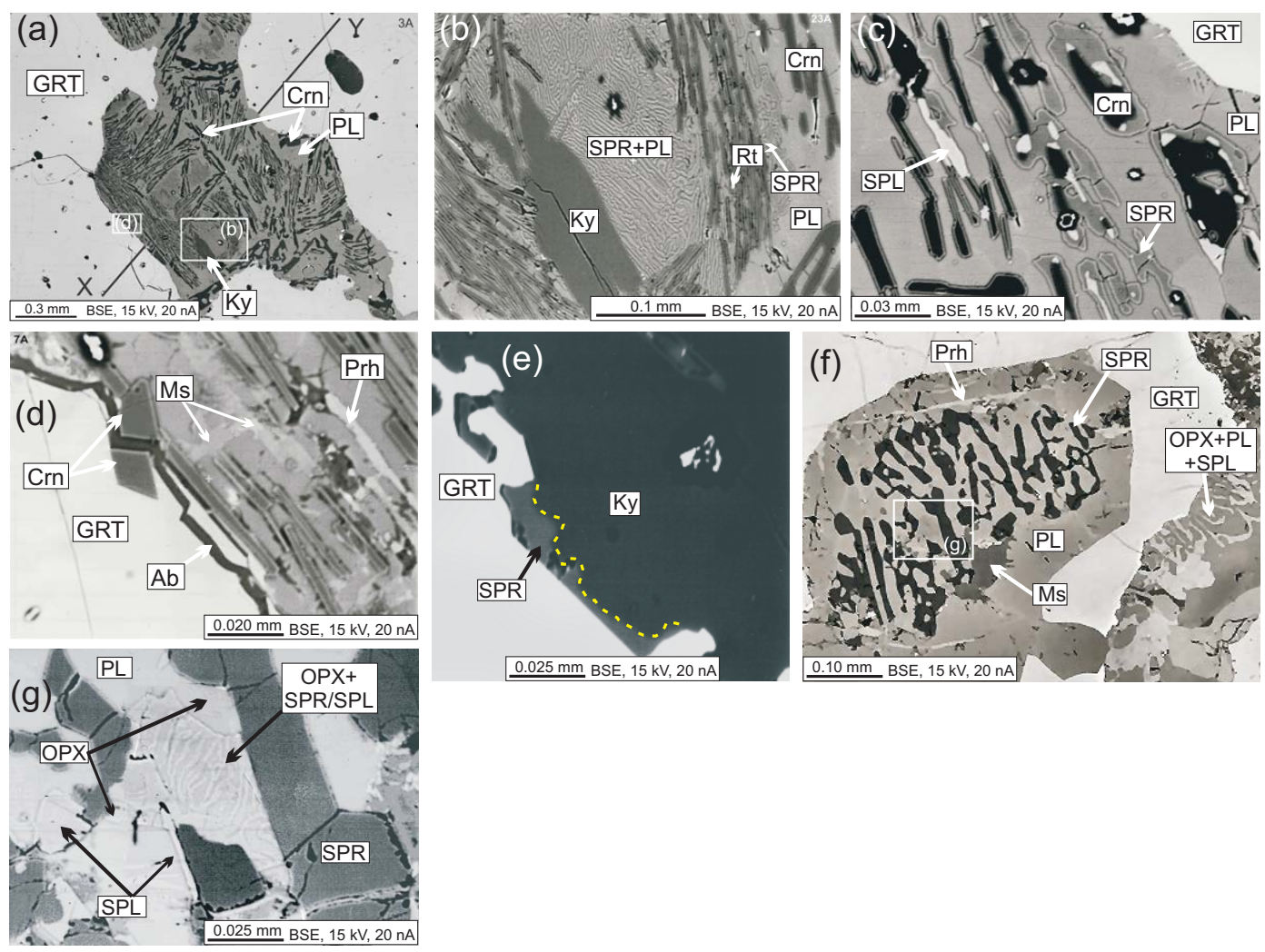

Figure 3. BSE images of inclusion-related symplectites. (a) Relict kyanite inclusion in garnet surrounded by Crn (black) + PL (middle gray) symplectite. The line X-Y refers to the profile in Figs. 5c and 6. The boxes (b) and (d) in panel (a) refer to panels (b) and (d), respectively. (b) Crn + PL symplectite seemingly enclosing an extremely fine-grained SPR + PL symplectite. (c) In fact, sapphirine has overgrown and consumed corundum that is intergrown with spinel. (d) Corundum intergrown with the reactive garnet edge. Note the late hydration products (white mica and prehnite) as well as a late crack filled with albite. (e) Sapphirine has overgrown the resorbing kyanite and is intergrown with the reactive garnet edge. The yellow dashed line emphasizes the resorption embayment of kyanite. (f) SPR + PL symplectite in garnet (see Fig. 2f). A plagioclase corona isolates the symplectite from garnet. Note that here kyanite is completely consumed. On the lower right part of this figure a typical garnet-rim symplectite (see Fig. 4a) is shown. In panel (f), the box labeled (g) refers to panel (g). (g) An extremely finegrained symplectite of OPX + SPR / SPL in the central part of the figure is seemingly enclosed in the coarse-grained SPR + PL symplectite. Note however, that spinel has overgrown sapphirine.

symplectite presumably replaced partially the coarsegrained SPR + PL symplectite. The whole symplectitic structure is enclosed in a plagioclase corona, which shows straight contacts with the broken-down garnet. All these features suggest that the current picture of the inclusion-related symplectites evolved during a multi-stage transformation process, whereby the initially formed corundum and the descendant sapphirine became successively metastable.

- Symplectites at garnet rims (Fig. 4a, b). This kind of symplectite comprises the observed kelyphites formed by reaction between the garnet rim and the rock matrix. It shows best the typical features of a symplectite microstructure. It consists of intergrowths of vermicular crystals replacing the garnet along a sharp garnet-symplectite reaction front. The older parts of the symplectite are distant to the garnet and comprise coarser-grained, rather granoblastic $(\mathrm{OPX}+\mathrm{SPL}) \mathrm{do}-$ mains (Obata, 2011). Towards the garnet, the symplectitic phases become younger, reducing their intergranular spacing (and size), and evolving to an intergrowth of fibrous crystals of OPX + PL increasingly aligned perpendicular to the garnet-symplectite interface (Fig. 4a; "Law of normality" in Obata, 2011). Hornblende is often observed within this kind of symplectites. It is either intergrown with plagioclase touching the reaction front and is, therefore, a late symplectitic phase (Fig. 4b), or it forms coarse-grained granular crystals distant to the reaction front (Fig. 4a). As shown in both figures, the outermost margins of the adjacent matrix plagioclase crystals are enriched in Ca. This type of symplectite is henceforth referred to as rim symplectite.

- Symplectites within mode I (extensional) garnet cracks (Fig. 2e, Fig. 4c, d). This type of symplectite shows a 

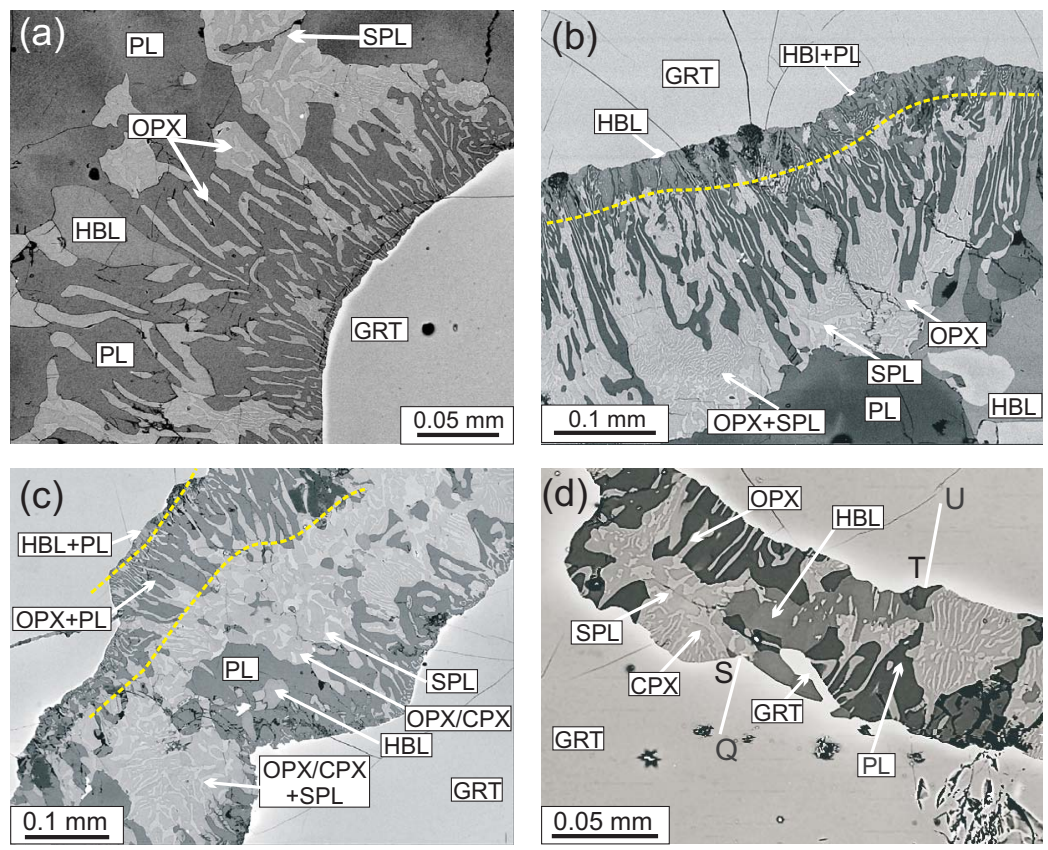

Figure 4. BSE images of rim and crack symplectites. Note in all figures the reduction of spacing (and size) of the symplectitic phases from the rock matrix $(\mathbf{a}, \mathbf{b})$ or the garnet crack middle line $(\mathbf{c}, \mathbf{d})$ towards the garnet-symplectite interfaces. Note also the light-colored narrow zones at the retreating garnet edges denoting the overprinted secondary diffusion profiles (see text) associated with the symplectite formation. (a) OPX + SPL + PL symplectite forming the kelyphites at garnet rims. At the left upper part of the figure, the matrix plagioclase crystals show a zonal pattern resulting from Ca enrichment of their margins. (b) Composite garnet kelyphite showing a OPX + SPL + PL symplectite adjacent to rock matrix evolving into an HBL + PL symplectite touching the garnet-symplectite interface. The approximate boundary between the two symplectites is highlighted by a yellow dashed line. In the lower central part of the figure, the outermost rims of coarse-grained matrix plagioclase show light-colored margins due to Ca enrichment. (c) Symplectite within a mode I (extensional) garnet crack showing a symmetric arrangement of the symplectitic phases about the middle line of the crack. The dashed yellow lines emphasize this zonal structure. At the upper left garnet edge, an OPX + PL symplectite evolved into an HBL + PL symplectite over very narrow zone. (d) CPX + OPX + SPL + PL symplectite within a garnet crack. The largest area of the symplectite is taken up by a clinopyroxene domain with intergrowths of tiny spinel crystals and a plagioclase domain with intergrowths of elongated vermicular orthopyroxene crystals. The intergrown tiny spinel and orthopyroxene crystals are mostly oriented perpendicular to the garnet-symplectite interface. Note also the remnant garnet within the kelyphite and the mode of occurrence of hornblende, which is strikingly different from that in Fig. 4c. Here, hornblende is most likely formed by recrystallization during and/or after replacement of orthopyroxene. The garnet profiles along the lines Q-S and T-U are shown in Fig. 5e.

symmetrical shape and size distribution of the phases on either side of the crack middle line. Along the middle line, coarser-grained orthopyroxene and clinopyroxene domains are intergrown with tiny vermicular spinel. Towards both garnet-symplectite interfaces, they evolved into fine-grained intergrowths of fibrous $\mathrm{OPX}+\mathrm{PL} \pm \mathrm{CPX}$ crystals oriented perpendicular to the reaction front. Thereby, inter-granular spacing (and size) of the symplectitic phases decreases. A few hornblendes are often present and follow the modes of occurrence described in rim symplectites. This type of symplectite is referred to below as crack symplectite.

All three types of symplectites were observed in one large garnet within one thin section. Rim and crack symplectites are mineralogically similar, bearing the assemblage $[\mathrm{OPX} \pm \mathrm{CPX}+\mathrm{SPL}]+\mathrm{PL}$. Clinopyroxene occurs however only in crack symplectites. Inherent to the formation of all three types of symplectite are the secondary compositional changes within 10s of micrometers across the retreating garnet edge. This is addressed in the next section.

\section{Mineral chemistry}

The mineral compositions (microprobe analyses) addressed below are given in the Supplement.

Besides the different types of symplectites, the largest garnets show systematic composition patterns. Figure 5a shows the element distribution profile $\mathrm{Z} 1-\mathrm{Z} 2-\mathrm{Z} 3$ across the garnet in Fig. 6. The Mn content in the garnets is generally very low. $\mathrm{Mg}, \mathrm{Ca}$ and $\mathrm{Fe}$ vary along the profile, but $\mathrm{Fe}$ shows the lowest variation. Along the profile, distinct element distribution patterns occur that may be observed repeatedly in all 

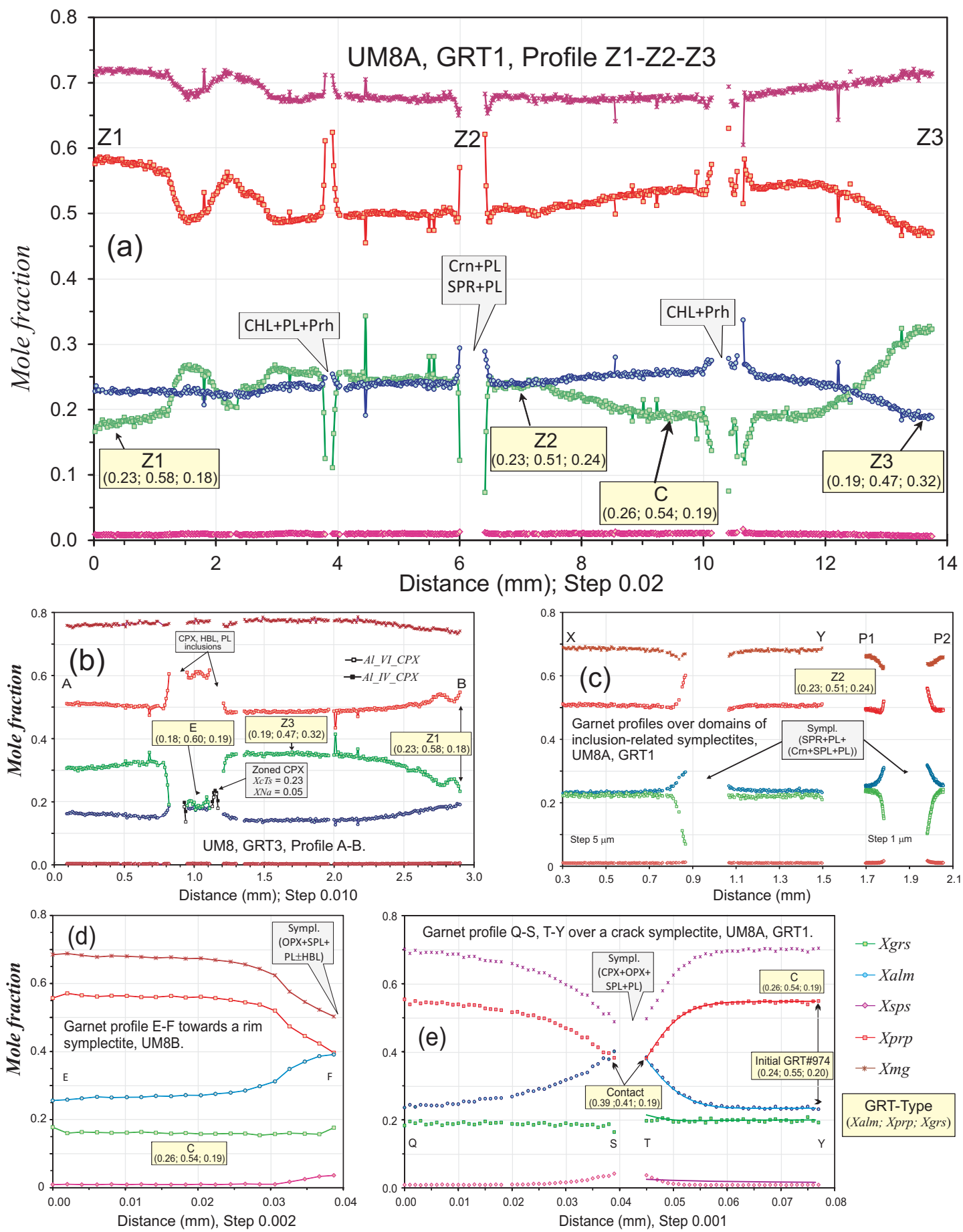

Figure 5. Composition of garnet. (a) Profile Z1-Z2-Z3 in the large garnet of Fig. 6. The specific compositional patterns occurring along this profile are standardized to GRT-types designated by yellow text boxes (see text and Fig. 2). These GRT-types are repeatedly observed in other garnets of the sample; see following figures. The yellow text boxes are given there for reference. (b) Profile across the middle-sized GRT-type Z3 shown in Fig. 2e. The GRT-type E occurs adjacent to clinopyroxene inclusions. Note the pronounced zoning in Al shown by a clinopyroxene inclusion. (c) The secondary diffusion profiles X-Y and P1-P2 may be located in Fig. 6. They overprint GRT-type C across complex, inclusion-related symplectites; see text and Fig. 3. (d) Profile of a GRT-type C towards a rim symplectite. Contrary to Ca, which remains unaffected, the diffusion curves of the other elements show an inversion point at $\sim 8 \mu \mathrm{m}$ ahead of the garnet edge. (e) The two profiles shown here can be found in Fig. 6. The curves are model diffusion profiles fitted at the analysis points by treating alm, prp and grs as independent components. Analyses of garnet in contact with the symplectite (contact garnet) and the seemingly unaffected garnet apart from the diffusion profile (initial garnet) are given in the Supplement, Table S2. 


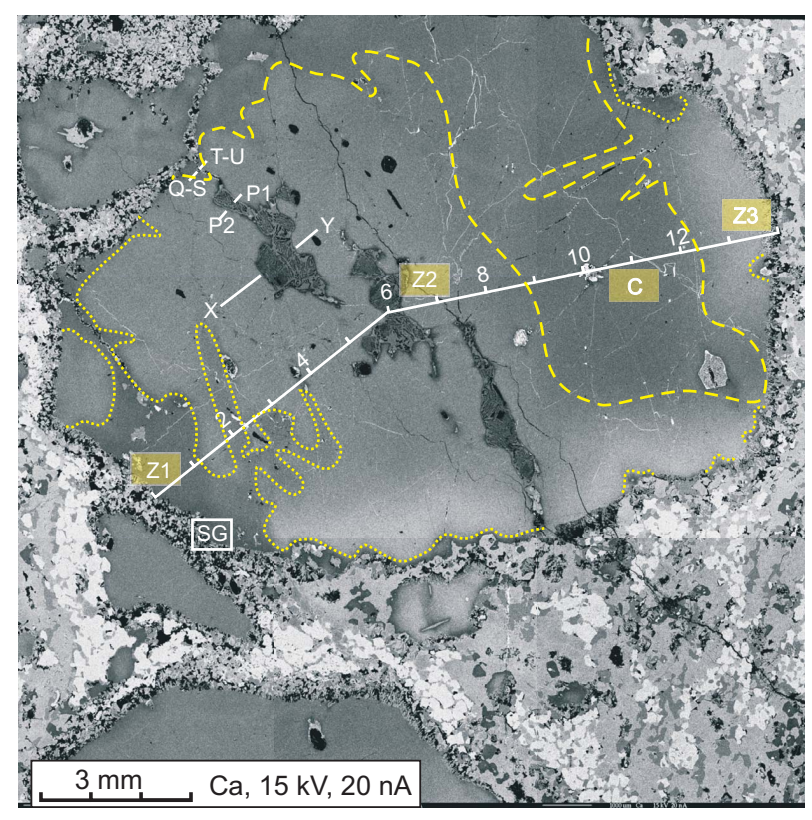

Figure 6. Ca distribution map in garnet. This $\mathrm{Ca}$ distribution map shows the large garnet in Fig. 2a. The profiles Z1-Z2-Z3, X-Y, P1$\mathrm{P} 2, \mathrm{Q}-\mathrm{S}, \mathrm{T}-\mathrm{U}$ and the areas designated with yellow boxes refer to the profiles and GRT-types (see text), respectively, shown in Fig. 5. The dashed line delimits the distribution of GRT-type C; the dotted line the distribution of GRT-type Z1. GRT-type Z3 (highest Ca content) is restricted along the lower and right margin of the garnet. Box SG shows the area where garnet subgrains as those in Fig. 8 occur.

other garnets of the rock (e.g., Fig. 5b, c, d, e). These patterns, addressed in the following as GRT-types Z1, Z2, C and $\mathrm{Z} 3$, are discerned on the basis of distinctly differing relations among $X_{\mathrm{alm}}, X_{\mathrm{prp}}$ and $X_{\mathrm{grs}}$ (Table 2). GRT-types Z1 and $\mathrm{C}$ share the same component relation characterized by $X_{\text {grs }}<X_{\text {alm }}<X_{\text {prp. }}$ GRT-type Z2 is characterized by lowest $X_{\text {prp }}$ and $X_{\text {alm }} \approx X_{\text {grs }}$. GRT-type Z3 shows the highest observed $X_{\text {grs }}$ and $X_{\text {alm }}<X_{\text {grs }}$. The specific triplets ( $X_{\text {alm }}$; $X_{\text {prp }} ; X_{\text {grs }}$ ) characterizing these GRT-types comprise component mole fractions averaged over dozens of homogeneously distributed garnet analyses along the profile Z1-Z2-Z3; see the Supplement for details. They are given in the yellow text boxes in Fig. 5a. Where relevant, these text boxes are included for reference in all other garnet profiles discussed below.

With the aid of the GRT-types defined in Fig. 5a, the Ca distribution map in Fig. 6 allows for mapping of their areal extent. The dashed line in Fig. 6 delineates the distribution of GRT-type C. The dotted line delineates the distribution of GRT-type Z1. The distribution of GRT-type Z3 is easily recognized by the high Ca content (light gray color in Fig. 6) at the right and lower margin of the garnet. GRT-type Z2 takes up the remaining part of the garnet.
GRT-type C occupies the large, inclusion-poor interior part of the garnet. GRT-type Z1 has evolved at a strongly Ca-depleted area along a garnet crack, which can be recognized in Fig. 2a and 6. Therefrom, it "intrudes" irregularly into the garnet interior and extends over a narrow zone along the lowest rim of the garnet. As can be recognized in Fig. 6, GRT-type Z1 cross-cuts GRT-type Z3 over a narrow transitional zone and is therefore younger. This age relation is also supported by the typical middle-sized garnet in Fig. 5b. This garnet is of type Z3, but has evolved into GRTtype Z1 towards its margin. Compared with the other GRTtypes shown in Fig. 6, GRT-type Z1 is a late feature related most probably with the action of metasomatizing agents. GRT-types Z2 and C are seemingly older, but their temporal interrelation is not clear. Their transition towards GRTtype Z3 is smooth. Despite their similar component relation $\left(X_{\mathrm{grs}}<X_{\mathrm{alm}}<X_{\mathrm{prp}}\right)$, we discriminate GRT-type C from GRT-type Z1 based on their strikingly different modes of occurrence described above. Based on these observations, the relative age relations of the garnet types may be summarized as follows: $\mathrm{Z} 1<\mathrm{Z} 3<\mathrm{Z} 2 \leq \mathrm{C}$. It is noteworthy that the garnet is replaced by kelyphite along its rim (see Fig. 6) and, as shown by the dotted line at the lowest garnet rim, only the younger GRT-type Z1 may be formed as late as the rim symplectite.

The garnet profiles in Fig. 5 show pronounced compositional zoning profiles that have evolved within $10 \mathrm{~s}$ of micrometers along the garnet interface with the symplectites. Such compositional zoning profiles within the reactive and retreating garnet edge are imposed over pre-existing garnet compositional patterns and are, therefore, secondary. As will be discussed later, their evolution is linked to the formation of the symplectites. Henceforth, such pronounced compositional profiles will be referred to as diffusion profiles.

A close inspection of Fig. 5 reveals that the diffusion profiles overprint the GRT-types Z2, C and Z3. Therefore, the associated symplectites are younger than the overprinted GRTtypes. For example, the strong $\mathrm{Ca}$ depletion at $6 \mathrm{~mm}$ adjacent to an inclusion-related symplectite (Fig. 5a) is imposed over GRT-type Z2. The same kind of depletion at $10.5 \mathrm{~mm}$ is imposed over GRT-type C. In Fig. 5b, this depletion is overprinted over GRT-type Z3. Such relations can be verified also in Fig. $5 c, d$ and e. As such overprinting relations have not been observed in the case of the younger GRT-type Z1, we conclude that symplectite formation is at earliest coeval to this garnet type and consequently younger than the internal compositional structure of the garnet related to GRT-types $\mathrm{Z} 2, \mathrm{Z} 3$ and $\mathrm{C}$.

The garnet profiles shown in Fig. $5 \mathrm{c}$ and e are acquired over domains of inclusion-related and crack symplectites, respectively. Figure $5 \mathrm{c}$ shows a diffusion profile within about $10 \mu \mathrm{m}$ towards the garnet-symplectite interface characterized by increasing $X_{\mathrm{prp}}$ and $X_{\mathrm{alm}}$, and sharply decreasing $X_{\mathrm{grs}}$. In Fig. 5e, the diffusion profile is characterized by unchanged $X_{\text {grs }}$, increasing $X_{\text {alm }}$ and decreasing $X_{\text {prp }}$. This striking dif- 

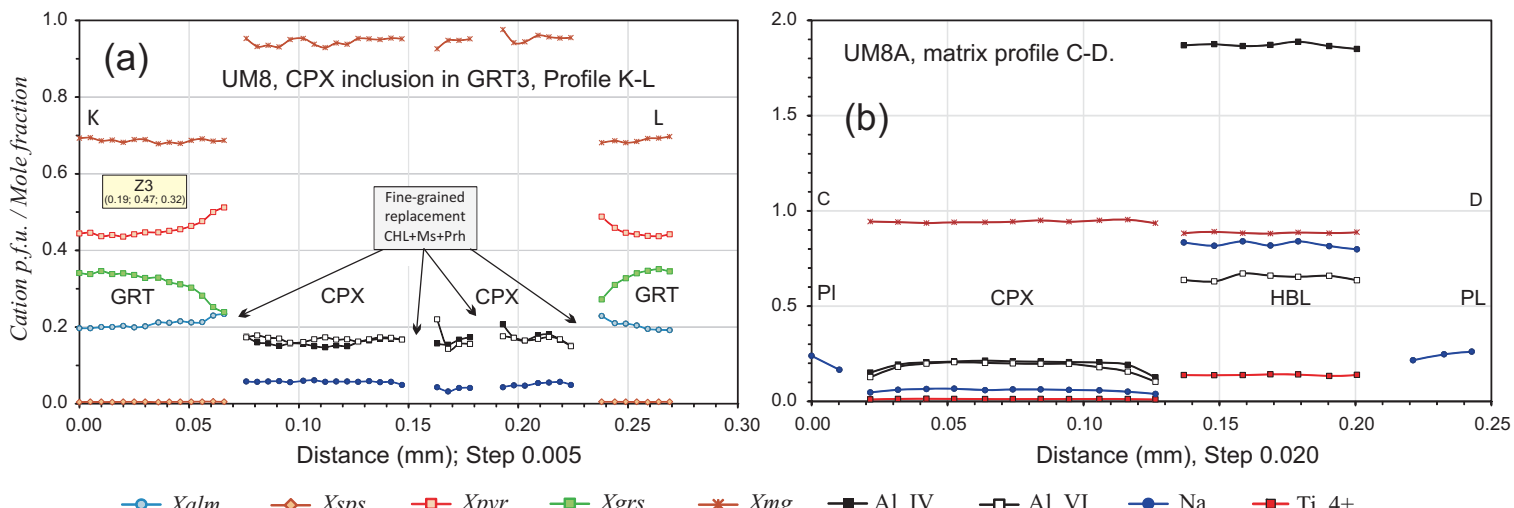

$\neg$ Xalm $\rightarrow$ Xsps $\rightarrow-$ Xpyr $\rightarrow$ Xgrs $\rightarrow$ Xmg $\rightarrow$ Al IV $\rightarrow$ Al_VI $\rightarrow$ Na $\rightarrow$ Ti $4+$

Figure 7. Clinopyroxene composition. (a) Profile K-L across a clinopyroxene inclusion in garnet. Contrary to the homogenized compositional pattern of the clinopyroxene, the adjacent garnet preserves a diffusion profile within $\sim 30 \mu \mathrm{m}$ towards the pyroxene. Note also the appreciable $\mathrm{Al}\left(X_{\mathrm{cTs}} \sim 0.20\right)$ and the very low Na contents of the clinopyroxene. (b) Profile C-D (see Fig. 2c) across matrix phases. Clinopyroxene and hornblende are completely homogenized by intra-crystalline diffusion. The composition of the clinopyroxene interior is similar to that of the inclusion shown in panel (a). Its outermost rim shows less $\mathrm{Al}\left(X_{\mathrm{cTs}} \sim 0.12\right)$ correlating negatively with the outermost rim of plagioclase showing an increased $X_{\text {an }}$ of $\sim 0.85$.

ference reflects primarily the influence of the local environment on their formation mechanism. In the case of Fig. 5c, the environment is defined by GRT-type Z2 reacting with its kyanite inclusions. In the case of Fig. 5e, it is defined solely by the instability of GRT-type C. Diffusion profiles at garnetrim symplectites are similar to those at crack symplectites. Occasionally, and as shown in Fig. 5d, the diffusion curves for $\mathrm{Mg}, \mathrm{Fe}$ and $\mathrm{Mn}$ adjacent to rim symplectites show an inflection point at some short distance before the retreating garnet edge.

Pronounced diffusion profiles in garnet are also observed towards clinopyroxene inclusion domains. As shown in Fig. 5b, the middle-sized GRT-type Z3 contains also GRTtype $\mathrm{E}$ in the vicinity of clinopyroxene inclusions. This type is characterized by the highest observed $X_{\text {prp }}$. Remarkably, one of the clinopyroxene inclusions crossed by the profile in Fig. $5 \mathrm{~b}$ shows a sharp zonal pattern with highest $\mathrm{Al}$ content in its core. Even for this seemingly "protected" inclusion, $X_{\mathrm{Na}}$ remained negligibly low. This clinopyroxene zoning is rather the exception. As shown in Fig. 7a, in contrast to the adjacent reactive garnet edges preserving diffusion profiles, clinopyroxene inclusions show a uniform element distributions $\left(X_{\mathrm{cTs}} \sim 0.20 ; X_{\mathrm{Na}} \sim 0.07\right)$. In fact, the composition of clinopyroxene inclusions does not differ significantly from the composition of the clinopyroxene crystals in the rock matrix (Supplement, Table S3).

Figure $7 \mathrm{~b}$ shows a profile across matrix crystals of plagioclase, clinopyroxene and hornblende. The element distribution within hornblende and clinopyroxene are perfectly uniform. This is interpreted as evidence of homogenization by intra-crystalline diffusion. The matrix clinopyroxene shows a similar composition as the inclusion discussed above. Only its outermost rim shows less $\mathrm{Al}\left(X_{\mathrm{cTs}} \sim 0.13, X_{\mathrm{Na}} \sim 0.05\right)$.
This change correlates with the Ca enrichment of the outermost plagioclase rims (see Fig. 2c). As shown in Fig. 2c, the interiors of some larger matrix clinopyroxene crystals contain very thin, analytically unresolved exsolution lamellae. Notably, the average of 120 point analyses carried out with de-focused beam in scanning mode over such an area of size $49 \mu \mathrm{m} \times 49 \mu \mathrm{m}$ does not differ significantly from the interior analysis of clinopyroxene.

Plagioclase in inclusion domains in garnet contain more $\mathrm{Al}$ $\left(X_{\text {an }} \sim 0.88\right)$ than the matrix crystals. The latter show interiors with uniform composition of $X_{\mathrm{an}} \sim 0.72$ and outermost rims of $X_{\text {an }} \sim 0.84$ (Fig. 2c; Supplement, Table S4). Plagioclase in inclusion domains of garnet was often partially or totally replaced pseudomorphically by prehnite. Very late hydration and replacement products composed mostly of finegrained aggregates of chlorite and sericite occur in almost all inclusion domains in garnet.

\section{Additional garnet textures}

Some large garnets show crystal-internal domains with pronounced contrast on the back-scatter electron (BSE) images in compositionally very homogeneous areas (Fig. 8). Forward scatter electron (FSE) images as well as orientation imaging using EBSD revealed that the observed contrast is due to the presence of subgrains with up to $12^{\circ} \mathrm{mu}-$ tual misorientation. The subgrains are related by rotation around a common axis coinciding with garnet [211]. Similar subgrain formation ascribed to intra-crystalline deformation by dislocation glide has been observed in granulites and upper mantle rocks (Kleinschrodt and McGrew, 2000; Kleinschrodt and Duyster, 2002). In the sample at hand, this deformation-induced feature can be observed only within the 


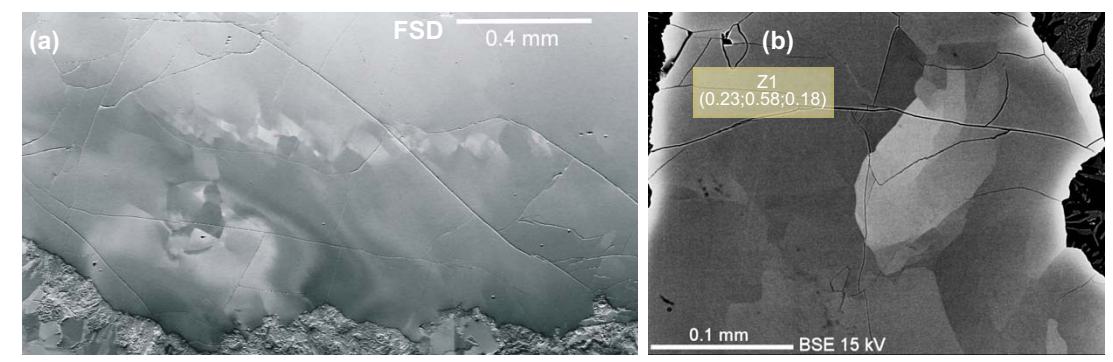

Figure 8. Images of orientation contrast of garnet subgrains within a GRT-type Z1. (a) Garnet subgrains aligned linearly and forming an imbrication microstructure. (b) Subgrain development within garnet. The secondary diffusion profile at the right garnet rim (thin light-colored zone) in contact with a rim symplectite has overprinted the subgrains containing garnet.

youngest GRT-type Z1. Notably, the diffusion profile (lightcolored zone) in contact with a rim symplectite at the right garnet rim (Fig. 8b), has overprinted the subgrain-containing garnet rim. Therefore, formation of the garnet subgrains within GRT-type Z1 predates symplectite formation.

Some other garnets exhibit a peculiar appearance resembling a poikiloblastic microstructure (Fig. 9). We use the designation "poikiloblastic" for these garnets without any genetic co-notation. They contain abundant rounded to vermicular plagioclase inclusions of rather large size ranging between several tens to about $200 \mu \mathrm{m}$. Such garnets closely resemble GRT-type Z1 and occur in the outermost 100 to $300 \mu \mathrm{m}$ of large garnets (Fig. 9a) or throughout small, up to about millimeter-sized garnets in the rock matrix (Fig. 9b). As can be recognized in the Fe distribution map in Fig. 9a, the poikiloblastic garnet is overprinted by the diffusion profile that is associated with the crack symplectite shown in the upper right part of the image. The poikiloblastic garnet is thus older than the crack symplectite. The plagioclase inclusions show uniform chemical composition, but differ significantly between the two poikiloblastic garnets shown in Fig. 9.

Garnet profiles acquired over crack symplectites (e.g., Fig. 5e) show that GRT-type $\mathrm{C}$ extends beyond the diffusionaffected part of the garnet. An analysis practically identical with GRT-type C and lying on this profile is \#974 (Supplement, Table S3). Modal analysis of the phases in crack symplectites (Figs. 4d, 5e) combined with their chemical composition obtained by microprobe analysis showed that the bulk symplectite composition is almost isochemical with the GRT-type C. The tools and methods of volumetric measurement of the symplectitic phases as well as the calculation of the bulk symplectite composition are described in the Supplement. The results are summarized in Fig. 10. They confirm that within the maximal uncertainty of less than $3 \%$ shown by $\mathrm{FeO}$, the integrated bulk symplectite is isochemical to the initial garnet \#974. However, some minor input of $\mathrm{SiO}_{2}, \mathrm{Na}_{2} \mathrm{O}$ and $\mathrm{CaO}$ to the bulk symplectite as well as some loss of $\mathrm{Al}_{2} \mathrm{O}_{3}, \mathrm{FeO}, \mathrm{MnO}$ and $\mathrm{MgO}$ from garnet appears to have taken place. It is most likely that this mass exchange was mediated by fluids. Despite these minor uncertainties, we consider the bulk symplectite as isochemical with garnet analysis \#974 (or GRT-type C), allowing thus for a straightforward thermodynamic modeling of the symplectite formation within a simple bulk chemical system defined by the composition of this garnet. This is presented in Sect. 8.3 (Synthesis).

\section{$7 \quad P-T$ evolution}

Despite the large variability of the observed features, two of them serve as staring points for modeling the $P-T$ evolution of the rock. The first one is the primary assemblage GRT + CPX + Ky. The composition space for this assemblage is the bulk rock composition. The second one is the crack symplectite assemblage $\mathrm{CPX}+\mathrm{OPX}+\mathrm{SPL}+\mathrm{PL}$ that is almost isochemical to GRT-type C. These assemblages fix two different stability fields that constrain the $P-T$ path. Although hornblende is occasionally present in small amounts in the inclusion domains of garnet and within some symplectites, we consider its formation as late due to extensive recrystallization and partial rehydration of the rock matrix that was set up during or after the latest stage of symplectite formation. This is discussed in detail in Sect. 8.3 (Synthesis). Therefore, the two assemblages above are considered free of primary hydrated minerals and independent of $a_{\mathrm{H}_{2} \mathrm{O}}$ at the time of their formation.

For the calculation of the stability fields of the assemblages GRT $+\mathrm{CPX}+\mathrm{Ky}$ and $\mathrm{CPX}+\mathrm{OPX}+\mathrm{SPL}+\mathrm{PL}$, the Theriak-Domino software (de Capitani and Petrakakis, 2010), version 03.01.2012 with the associated database file jun92.bs, was used. Because of the appreciable amounts of the $c T s$ component in the measured clinopyroxene and the lack of appropriate $a-x$ relations, a three-site ideal mixing model for clinopyroxene comprising the phase components $d i, h d, c T s$ and $j d$ was formulated. Sapphirine was omitted, as the available data seem to be inappropriate for the peculiar bulk composition of this rock. Therefore, some parts of the following diagrams between the stability fields of the above two assemblages may be metastable with respect to 

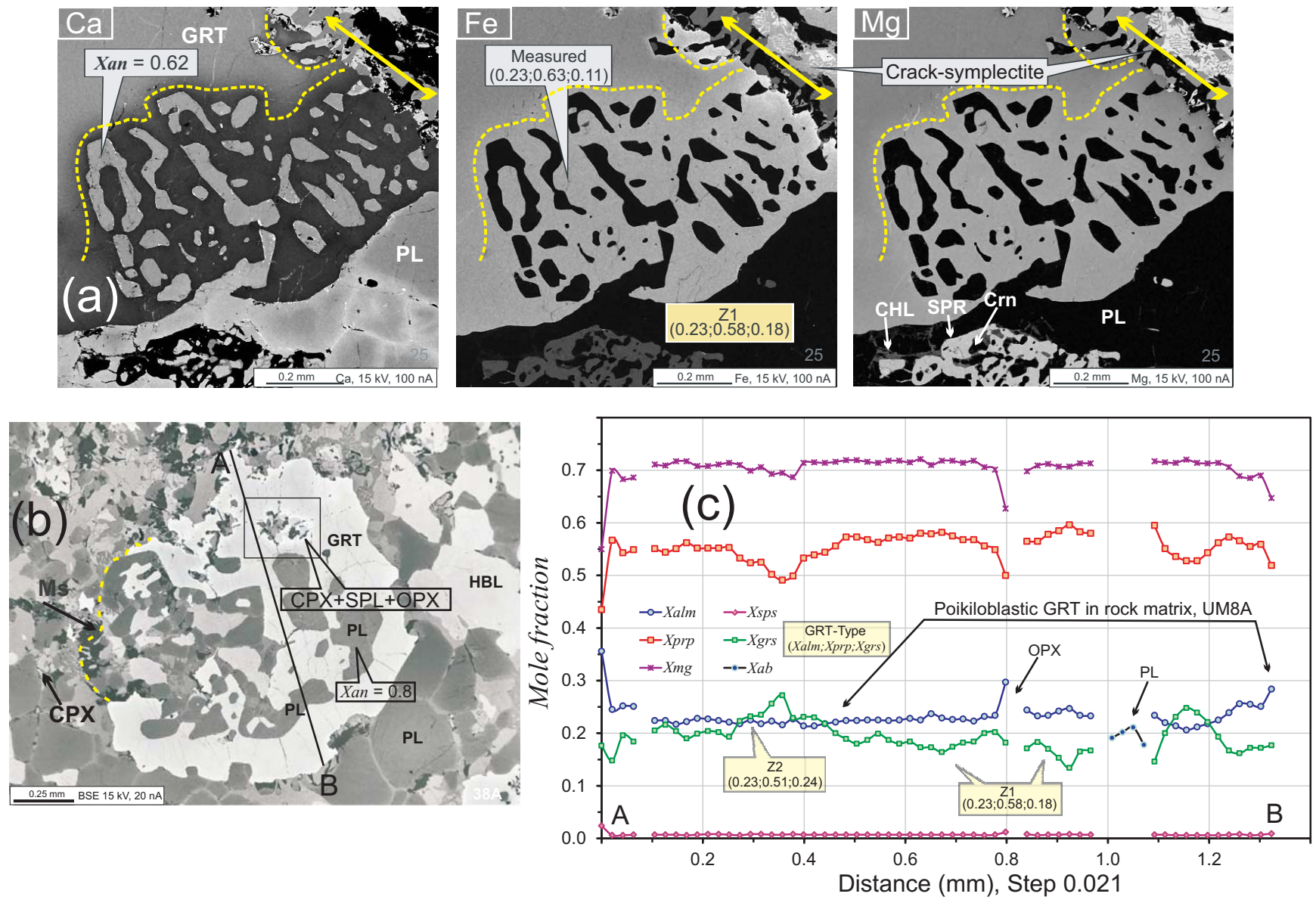

Figure 9. The poikiloblastic garnets. The designation of these garnets is based on their resemblance with the common poikiloblastic microstructure. It is used without any genetic co-notation. (a) $\mathrm{Ca}, \mathrm{Fe}$ and $\mathrm{Mg}$ distribution maps at the rim of a large garnet evolving towards a poikiloblastic GRT-type Z1. The dashed lines delineate the poikiloblastic garnet. At its upper right part signified with a double yellow arrow, a symmetrical crack symplectite containing an OPX + SPL domain cross-cuts the poikiloblastic garnet. The associated pronounced diffusion profile (best seen in the Fe distribution map) overprints the poikiloblastic garnet. (b) BSE image of an poikiloblastic garnet in the rock matrix. The inclusion domain in the rectangle shows a diffusion profile around clinopyroxene, orthopyroxene and spinel inclusions. (c) Profile across the garnet in panel (b). The garnet close to the plagioclase inclusions shows a homogenized element distribution resembling that of GRT-type Z1. Close to the inclusion domain shown in panel (b), the element distribution resembles rather that of the older GRT-type Z2.

sapphirine. Because of the very low, almost negligible Mn content in garnet and bulk rock, we added the minor Mn to $\mathrm{Fe}$ and utilized the ternary mixing model for garnet included in the database. We also omitted the very low contents of $\mathrm{K}$ measured in the rock and the minerals as well as P.

The equilibrium assemblage $P-T$ diagram (pseudosection) of Fig. 11a is based on the bulk rock composition. It reproduces well the two target assemblages mentioned above. The inset in Fig. 11b shows the same diagram expanded up to $20 \mathrm{kbar}$. The primary assemblage GRT $+\mathrm{CPX}+\mathrm{Ky}$ is stable at $P>11 \mathrm{kbar}$ and $T$ between 760 and $880^{\circ} \mathrm{C}$. From there, the stability field of the crack symplectite assemblage CPX + OPX + SPL + PL may be reached by more or less isothermal decompression to pressures of less than $9 \mathrm{kbar}$, but higher than $\sim 5 \mathrm{kbar}$. This low
$P$ limit is constrained by the absence of olivine in the symplectites.

Figure $11 \mathrm{~b}$ shows the isopleths of garnet equilibrium composition. If an original growth zoning acquired during propagation of the garnet growth front at local equilibrium was preserved without any modification by intra-crystalline diffusion, all component isopleths should intersect at a single $P-T$ point. Based on this figure, Fig. 11c shows the isopleths distribution for the observed GRT-types. According to the applied thermodynamic model, for none of the GRT-types does a common intersection point of the isopleths for the measured $X_{\text {alm }}, X_{\text {prp }}$ and $X_{\text {grs }}$ exist. We consider this as an indication of perturbation of garnet composition from equilibrium. This holds not only for the stability field of the primary assemblage, but also for all other assemblages shown in Fig. 11a. This indicates that the garnet composition was 


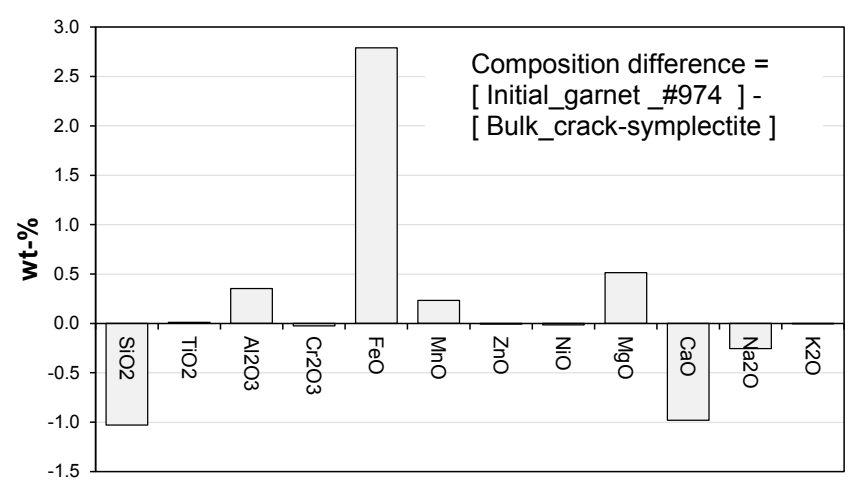

Figure 10. Difference between the composition of the initial garnet and the bulk composition of the crack symplectite. See also Figs. 5e and $4 \mathrm{~d}$.

modified substantially during the evolution of the rock. Fe appears to have been partially lost and homogenized towards lower values for all garnet types. In the case of GRT-types Z3 and E, the measured $X_{\text {alm }}$ isopleth lies far beyond the right side of the figure. The prp isopleths are much less dispersed and lie closest to the stability field of the primary assemblage. Ca seems to "resist" extensive modification, perhaps "memorizing" a prograde $P-T$ past of the rock, especially within the Ca-rich GRT-type Z3. Taking however into account the relative timing of the garnet types $(\mathrm{Z} 1<\mathrm{Z} 3<\mathrm{Z} 2 \leq \mathrm{C})$, it becomes evident that, for example, the Ca-rich GRT-type Z3 cannot reflect some earlier preserved $P-T$ information. In this case, GRT-type Z3 should be the oldest compositional element of the complex garnet structure. Indeed, if Fe was partially removed from the garnet (see also Fig. 10) pushing the measured $X_{\mathrm{alm}}$ far to the right of Fig. 11c, the contents of $\mathrm{Ca}$ and $\mathrm{Mg}$ in garnet should have increased due to stoichiometric constrains. This increase should have displaced the isopleth of the measured $X_{\mathrm{grs}}$ to the left and the isopleth for the measured $X_{\text {prp }}$ to the right of this figure. The opposite is certainly also true. Therefore, the measured higher Ca contents in some GRT-types do not necessarily reflect preserved past $P-T$ information.

Evaluating the degree of deviation of the various GRT-type isopleths from equilibrium by their proximity to the stability field of the primary assemblage, it may be concluded that GRT-type C occurring in the inner part of the garnet is the least disturbed type with its grs isopleth still lying within this stability field. We consider therefore GRT-type C as the best available garnet composition approaching better the stability field of the primary assemblage.

The measured compositions of inclusions in garnet are compared with calculated compositions along the decompression path shown in Fig. 11d. The pressure range 15 to $6 \mathrm{kbar}$ at $825^{\circ} \mathrm{C}$ is thought to be representative of the decompression implied by Fig. 11a. With the exception of garnet for $P<12 \mathrm{kbar}$, the calculated equilibrium composition of the minerals is rather insensitive to $P$ change. The $c T s$ and $j d$ contents in clinopyroxene are predicted to decrease slightly with decreasing pressure. Plagioclase is stable below $\sim 12$ kbar outside the stability field of the primary assemblage. Therefore, the plagioclase observed in inclusion domains in garnet is secondary. The calculated composition of plagioclase remains unchanged down to $6 \mathrm{kbar}$. Noticeably, the measured composition of plagioclase inclusions is in excellent agreement with the calculated one. The measured $X_{\mathrm{mg}}$ and $X_{\mathrm{Al}, T}$ of the clinopyroxene inclusions are very close to the calculated values. The clinopyroxene is $d i$ rich and contains an appreciable $c T s$ component. In contrast, the measured $X_{\mathrm{Na}}$ shows the largest deviation from its calculated value pointing to almost complete loss of $\mathrm{Na}$. This loss is probably related to the stabilization of plagioclase below $\sim 12 \mathrm{kbar}$ as well as to the formation of hornblende and the recrystallization of the matrix after decompression. This view is corroborated by the fact that the composition of the clinopyroxene inclusions is very similar to the composition of the clinopyroxene in the rock matrix.

The calculated results for the symplectite assemblage $\mathrm{CPX}+\mathrm{OPX}+\mathrm{SPL}+\mathrm{PL}$ provide more and more reliable information on the $P-T$ evolution of the rock. Figure $12 \mathrm{a}$ is an equilibrium assemblage diagram (pseudo-section) calculated for a bulk composition equaling the initial garnet analysis \#974 shown in Fig. 5e. A minor amount of quartz was added to this composition in order to suppress the formation of olivine implied by the excess $\mathrm{SiO}_{2}$ of the bulk symplectite over the initial garnet; see Fig. 10 and Sect. 6. This quartz was quickly consumed during the first calculated steps of decompression shown in Fig. 12b. The stability field of the target assemblage $\mathrm{CPX}+\mathrm{OPX}+\mathrm{SPL}+\mathrm{PL}$ in Fig. 12a refines the magnitude of decompression down to pressures between 5 and $7.5 \mathrm{kbar}$ and temperatures above $730^{\circ} \mathrm{C}$.

In Fig. 12b, the calculated mineral compositions are compared with those measured within the symplectite. Again, the pressure range $6-15 \mathrm{kbar}$ at $825^{\circ} \mathrm{C}$ is thought to be representative of the decompression. It is interesting to note that the measured initial garnet composition (a GRT-type C) lies close to the calculated garnet composition, for example at $15 \mathrm{kbar}$. The diagram predicts that during decompression the garnet equilibrium composition remains fairly stable down to pressures of $\sim 9 \mathrm{kbar}$. Then, it changes continuously to its terminal composition lying at $\sim 7.8 \mathrm{kbar}$. The agreement between the compositions of the contact and terminal garnet is particularly good, especially in the case of $\mathrm{Ca}$ and $\mathrm{Fe}$. This corroborates the view that, in contrast to clinopyroxene and plagioclase, garnet did not suffer further modification by post-decompression recrystallization. The large discrepancy between the measured and the calculated clinopyroxene compositions is due to the Na-free bulk composition used in the calculation. Accordingly, the calculated plagioclase in equilibrium with the phases shown in Fig. 12b is pure anorthite, instead of the observed plagioclase with $X_{\text {an }}=0.95$ (Supplement, Table S5). 

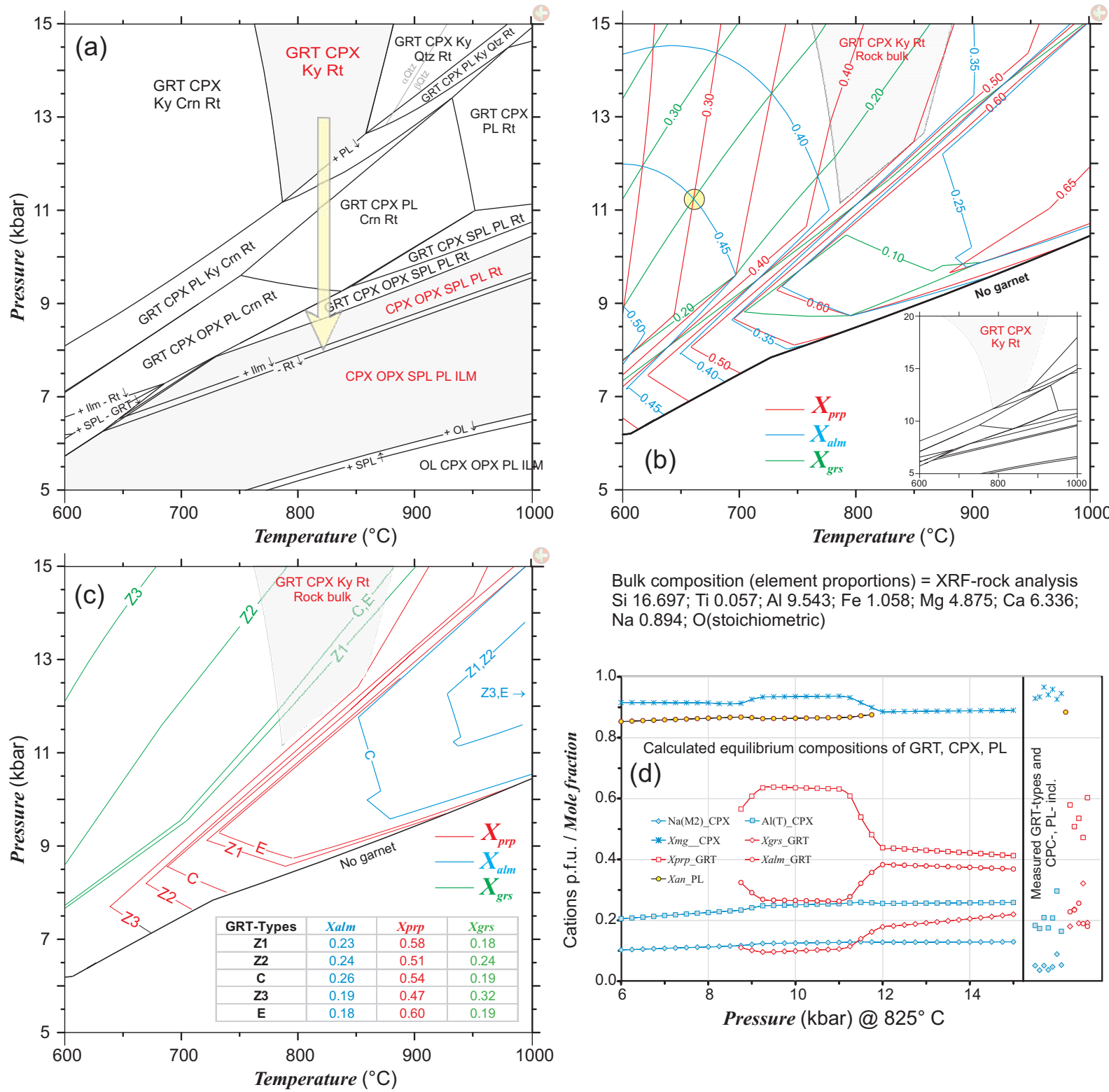

Bulk composition (element proportions) $=$ XRF-rock analysis Si 16.697; Ti 0.057; Al 9.543; Fe 1.058; Mg 4.875; Ca 6.336; $\mathrm{Na} 0.894 ; \mathrm{O}$ (stoichiometric)

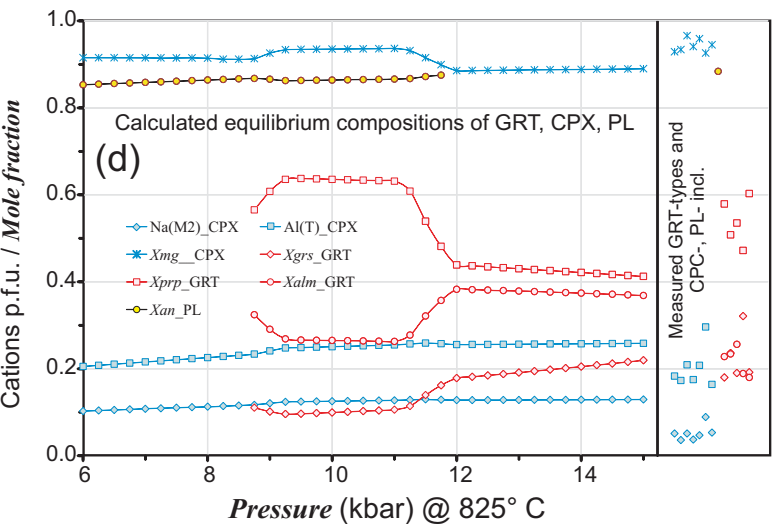

Figure 11. $P-T$ diagrams and composition of phases in sample UM8. (a) Equilibrium assemblage $P-T$ diagram (pseudo-section) based on the bulk rock composition reproducing well the observed primary assemblage GRT $+\mathrm{CPX}+\mathrm{Ky}+\mathrm{Rt}$ and the later formed crack symplectite assemblage CPX + OPX + SPL + PL + ILM. The arrow denotes schematically the transition by isothermal decompression from the former to the latter assemblage. (b) Isopleths of the modeled ternary garnet equilibrium composition. The shaded area corresponds to the stability field of the primary assemblage. The yellow circle emphasizes the necessity of a common intersection point of the isopleths in the case of a preserved equilibrium composition. The inset $P-T$ diagram is an extension of panel (a) up to $20 \mathrm{kbar}$. (c) Implied isopleths of the measured GRT-types and their proximity to the stability field of the primary assemblage denoted by the shaded area. The inset table summarizes the composition of the GRT-types. (d) Comparison of the measured GRT-types, clinopyroxene and plagioclase inclusions with their calculated equilibrium mineral compositions in the range $6-15 \mathrm{kbar}$ at $825^{\circ} \mathrm{C}$.

Besides the contact garnet composition, the applied thermodynamic model also reproduces very well the measured modal distribution of the symplectitic phases (Table 3).

The above results are not biased by any external thermobarometric references. They are based solely on the bulk composition of the rock or on the initial garnet that were in- put to the applied thermodynamic model. The overall nonequilibrium state of the garnet has been established not only by the $\mathrm{Ca}$ distribution map shown in Fig. 6, but also by checking if the grs, alm and prp isopleths cross each other at a single point, providing evidence of preserved equilibrium (Fig. 11c). The calculated equilibrium assemblage diagrams 

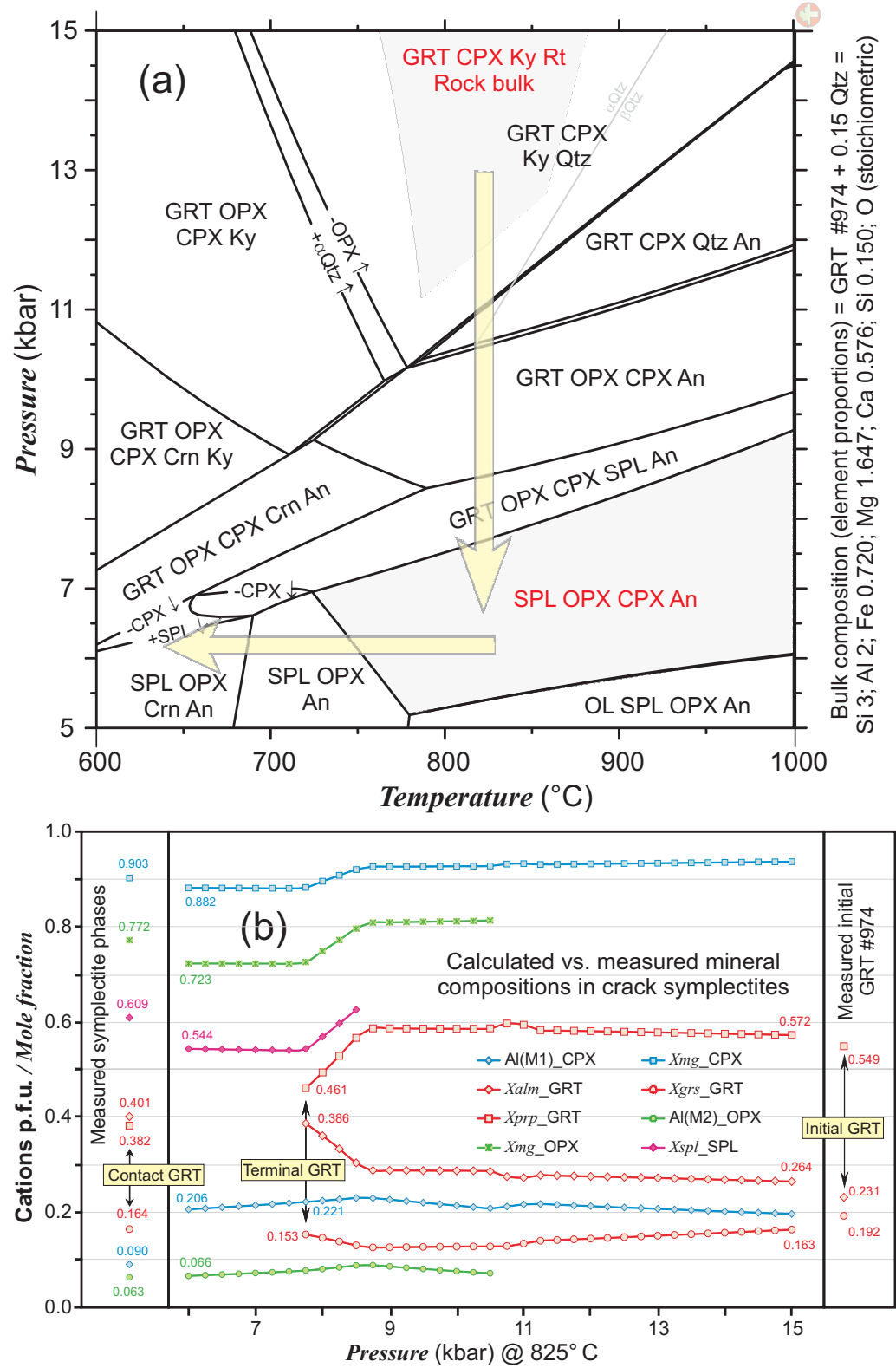

Figure 12. Isochemical breakdown of garnet to crack symplectite. (a) Equilibrium assemblage $P-T$ diagram (pseudo-section) for a bulk composition equaling the composition of the initial garnet shown in Fig. 5e. The upper shaded area corresponds to the stability field of the primary assemblage GRT + CPX + Ky in Fig. 11a. The lower shaded area corresponds to the refined stability field of the observed crack symplectite CPX + OPX + SPL + PL shown in Fig. 4d. The decompression arrow shows schematically the transition from the former to the latter assemblage. For the cooling arrow, see discussion in Sect. 8.3. (b) Calculated mineral equilibrium composition along the decompression denoted by the arrow in panel (a). The terminal garnet is the last calculated composition before complete garnet elimination. The contact garnet is the spatially best resolved analysis of the retreating garnet edge in contact with symplectitic phases. Measured compositions of the initial garnet and symplectitic pyroxenes and spinel (see Fig. 5e) are shown for comparison. The results are summarized in Table 3.

reproduce well the observed assemblages and, in the case of the isochemical breakdown of garnet to the crack symplectite, the measured compositions and volumes of garnet and symplectitic phases.

\section{Discussion}

\subsection{Symplectite formation}

Despite the single $P-T$ history experienced by the rock, the observed symplectite diversity points to the influence of the local environment on their formation. The inclusion-related 
Table 3. Calculated vs. measured composition and volume of clinopyroxene, orthopyroxene, spinel and plagioclase making up crack symplectites. The calculated compositions and volumes are based on a bulk composition equaling the initial garnet in Fig. 5e. Methods of volumetric analysis and calculation of bulk symplectite composition are described in the Supplement.

\begin{tabular}{|c|c|c|c|c|c|}
\hline \multicolumn{3}{|c|}{ Composition } & \multirow[t]{2}{*}{ Phase } & \multicolumn{2}{|c|}{ Volume- $\%$} \\
\hline & Calculated $^{\mathrm{a}}$ & Measured & & Calculated $^{\mathrm{a}}$ & Measured \\
\hline $\mathrm{Al}_{(T)}$ & 0.221 & 0.090 & & & \multirow{5}{*}{$47.4^{\mathrm{b}}$} \\
\hline$X_{\mathrm{mg}}$ & 0.882 & 0.903 & CPX & 0.7 & \\
\hline$X_{\mathrm{Na}}$ & & 0.021 & & & \\
\hline $\mathrm{Al}_{(M 1)}$ & 0.077 & 0.063 & \multirow{2}{*}{ OPX } & \multirow{2}{*}{47.2} & \\
\hline$X_{\mathrm{mg}}$ & 0.726 & 0.772 & & & \\
\hline$X_{\mathrm{mg}}$ & 0.543 & 0.609 & SPL & 10.1 & 12.3 \\
\hline$X_{\text {an }}$ & 1.000 & 0.945 & PL & 40.1 & 40.3 \\
\hline$X_{\mathrm{alm}}$ & 0.386 & $0.394^{c}$ & \multirow{3}{*}{ GRT $^{d}$} & \multirow{3}{*}{1.9} & \multirow{3}{*}{0.0} \\
\hline$X_{\text {prp }}$ & 0.461 & 0.414 & & & \\
\hline$X_{\text {grs }}$ & 0.153 & 0.185 & & & \\
\hline
\end{tabular}

${ }^{\text {a }}$ Calculated at $825^{\circ} \mathrm{C}, 7.75 \mathrm{kbar}^{\mathrm{b}}$ Value includes $8.1 \% \mathrm{HBL}$ considered to be substitute for CPX. CPX and OPX are not differentiated because they showed the same gray color in BSE images during volumetric analysis. ${ }^{\mathrm{c}}$ Value includes $X_{\mathrm{sps}}=0.027 .{ }^{\mathrm{d}}$ Given GRT values correspond to terminal (calculated) and contact (measured) garnet (see Fig. 12).

symplectites are the products of reaction of garnet with its kyanite inclusions. The rim symplectites are the products of reactions of the garnet rim with the rock matrix. The crack symplectites are the products of partial break-down of garnet alone under conditions of reduced stability. This led to the presumption that the crack symplectites are more or less isochemical to the garnet. This presumption has been verified by measurement of volume and composition of the symplectitic phases and by the results of the applied thermodynamic modeling.

Symplectite formation requires three processes to occur simultaneously. Firstly, chemical components must be redistributed at the reaction front because the precursor garnet (being considered chemically homogeneous on the scale of the forming symplectite) is replaced by an intergrowth of the chemically distinct symplectite phases at a sharp reaction front. The redistribution of these components occurs by diffusion within the reaction front (Gaidies et al., 2017). Secondly, for the reaction front to propagate, bonds must be broken in the precursor garnet at the leading edge of the reaction front, and new bonds must be established at its trailing edge forming the symplectite phases. The bulk of this process is referred to as interface reaction. And thirdly, new interfaces are formed separating the different symplectite phases.

Symplectite formation is initiated by a change in the environmental conditions of the rock. In the case of the sample at hand, this change is characterized by decompression at more or less constant high temperature. The garnet in contact with the newly forming symplectitic phases has a distinctly different composition from the broken-down garnet. This composition difference sets up transient gradients in chemical po- tential of the garnet components that decay with time. This process implies a time-dependent change of the composition of the broken-down and retreating garnet edge that is accomplished by intra-crystalline diffusion. This change in composition is accompanied by recrystallization. In the case of the inclusion-related symplectites, this recrystallization led to a garnet edge that overgrew its own broken-down products (Fig. 3d, e). The measured diffusion profiles at the brokendown and retreating garnet edge (Fig. 5) reflect the "frozenin" state of the above mentioned transient gradients at some time past the very first formation of the symplectite phases. Therefore, they allow us to calculate the timescale of symplectite evolution. This is discussed in the next section.

It is suggested that the frequently observed change of characteristic inter-granular spacing (and size) of the symplectite phases correlates positively with the temperature of symplectite formation. Remmert et al. (2018) presented experimental evidence corroborating this view and argued that the characteristic spacing of symplectite phases is small at low temperatures, whereby symplectite formation tends to be diffusion controlled. The characteristic spacing becomes larger at higher temperatures, whereby diffusion is more efficient, and symplectite formation becomes interface reaction controlled. The systematic decrease of the characteristic spacing of the symplectite phases from the older, external portions to the younger internal portions of the symplectite is observed in the rim and crack symplectites described above (Fig. 4).

EBSD analysis revealed a crystallographic orientation relationship (COR) between orthopyroxene and spinel in the rim and crack symplectites (see Supplement, Fig. S1). According to Obata (2011) and Obata and Ozawa (2011), CORs 
occur in symplectites around garnet in ultramafic rocks that have formed at temperatures higher than $\sim 800^{\circ} \mathrm{C}$; they are missing in symplectites that have formed at much lower temperatures. In the samples at hand, the COR between orthopyroxene and spinel is observed in both the early coarse-grained portions and the late fine-grained portions. Therefore, the $T$ change monitored by the symplectites of this study is rather small.

In summary, the studied symplectites were formed most probably during cooling of the rock, but still at high temperature. It is thus very likely that the onset of symplectite evolution coincides with the transition from the more or less isothermal rock decompression to more or less isobaric cooling (see Fig. 12a). This stage of rock evolution is discussed in Sect. 8.3 (Synthesis).

\subsection{Timescale of symplectite formation}

The systematic compositional changes of garnet towards the interfaces to the symplectite can be explained by reequilibration of the garnet that was mediated by intracrystalline cation diffusion. One of the best examples observed in the studied samples refers to the crack symplectite shown in Fig. 4d and the associated garnet profiles in Fig. 5e. The typically low Mn content of the garnet increases slightly towards the garnet-symplectite interface. This is probably due to the fact that the symplectite assemblage cannot accommodate the entire $\mathrm{Mn}$ of the garnet, which is then "pushed back" into the reactant garnet volume, where it is passively enriched immediately ahead of the symplectite reaction front. The $\mathrm{Ca}$ content remains largely unaffected, whereas $\mathrm{Fe}$ is successively enriched and $\mathrm{Mg}$ successively depleted towards the garnet-symplectite interface. The interdiffusion of $\mathrm{Ca}, \mathrm{Mg}$, Fe and $\mathrm{Mn}$ in garnet was modeled using a 1-D implicit finite difference method. The diffusion coefficients were taken from Chakraborty and Ganguly (1992). Fixed concentration boundary conditions were defined by the contact garnet closest to the garnet-symplectite interface $\left(X_{\mathrm{alm}}=0.37 ; X_{\mathrm{prp}}=0.41 ; X_{\mathrm{grs}}=0.19\right)$ and the initial garnet $\# 974\left(X_{\mathrm{alm}}=0.24 ; X_{\mathrm{prp}}=0.55 ; X_{\text {grs }}=0.20\right)$; see Fig. 5e and Supplement, Table S2. Mn ( $\left.X_{\text {sps }}\right)$ was treated as the dependent component. To minimize cutting effects, the shortest profile T-U shown in both figures was selected. Fitting of the model curves to the measured point analyses in Fig. 5e yielded timescales of 340, 20 and 1.5 years for the assumed temperatures of 700,800 and $900^{\circ} \mathrm{C}$, respectively. On the geological timescale, this corresponds to an ephemeral event. Such short-term diffusion cannot be explained by cooling alone. As will be discussed below, interface reactions responsible for symplectite formation is substantially mediated by the presence of fluid $\mathrm{H}_{2} \mathrm{O}$. A limited availability of such fluids may inhibit the progress of symplectite formation.

\subsection{Synthesis}

The complex compositional structure of the garnet in Fig. 6 cannot be explained simply as a (partially) preserved growth or (partial) homogenization at high-temperature conditions. Additionally and as shown by the measured isopleths, the composition of all garnet types seems to deviate from equilibrium. The "older" GRT-type C occupies the large interior part of the garnet; its composition shows the least deviation from equilibrium, corresponding closest to $P-T$ conditions of the stability field of the primary assemblage GRT + CPX + Ky. The Ca-rich GRT-type Z3 occupies a wide zone parallel to the garnet rim showing the largest observed deviation from equilibrium. GRT-type Z1 is the youngest garnet type, which demonstrates the most obvious relationship with the action of metasomatizing agents. It is formed along a garnet crack, intrudes irregularly the garnet interior and extends into a narrow zone along the garnet rim. Finally, the distribution of garnet types in Fig. 6 shows a relative timing of formation that can be summarized by $\mathrm{Z} 1<\mathrm{Z} 3<\mathrm{Z} 2 \leq \mathrm{C}$.

All these features provide convincing evidence that the garnet shown in Fig. 6 underwent diffusion-aided metasomatic modification during the late stages of its evolution represented best by GRT-types Z3 and Z1. Accordingly, the "younger" GRT-type Z3 might have evolved from the "older" GRT-type C by removal of a total amount of $12 \mathrm{~mol} \%$ of $\mathrm{Fe}+\mathrm{Mg}$ (Table 2; Fig. 5a). Recalling that GRT-type Z3 predates symplectite formation and that the GRT-type Z1 shows intra-crystalline deformation (Fig. 8) due to tectonic displacement (see below), we may conclude that the metasomatic alteration that formed GRT-types Z3 and Z1 might have taken place under $P-T$ conditions close to the conditions of the primary assemblage. An obvious metasomatizing agent might have been an anatectic melt and/or its accompanying fluids derived from the adjacent felsic rocks (see Hasalová et al., 2008a). Interestingly, Štípská et al. (2014a, b) inferred anatectic melts and fluids capable of transforming eclogites embedded in felsic granulites of the Blanský les massif into intermediate garnet and pyroxene-bearing granulites at pressures of $\sim 12 \mathrm{kbar}$, but at a higher temperature of $950^{\circ} \mathrm{C}$.

The calculated equilibrium assemblage diagram in Fig. 11 constrains the lower pressure of $11 \mathrm{kbar}$ at $\sim 800^{\circ} \mathrm{C}$ for the stability of the primary assemblage GRT $+\mathrm{CPX}+\mathrm{Ky}$. Due to compositional modification of garnet and resetting of clinopyroxene inclusions, a reliable estimate of pressure is questionable. Nevertheless, these conditions are comparable to peak conditions of $14.5 \pm 2 \mathrm{kbar}$ and $870 \pm 50^{\circ} \mathrm{C}$ estimated by Johansson and Möller (1986) for the same primary assemblage in mafic rocks of similarly $\mathrm{Mg}$-, Al- and Ca-rich composition from Roan, Western Gneiss Region, Norway. Incidentally, these Norwegian rocks have evolved during retrogression to an "intermediate $P$ " granulite com- 
prising orthopyroxene, spinel, anorthite, andesine, sapphirine and corundum (Johansson and Möller, 1986).

Associated with the latest GRT-type Z1 are the poikiloblastic garnets with their numerous plagioclase inclusions. As shown in Fig. 9, these garnets evolved continuously on or from pre-existing, inclusion-poor garnet. Texturally very similar poikiloblastic garnets with numerous plagioclase inclusions have been described by Racek et al. (2008) in garnet- and pyroxene-bearing granulites of the Sankt Leonhard granulite massif (their sample D454). As these garnets did not match well with the other features observed in their samples, the authors referred to them as "enigmatic". Despite the chemical and paragenetic differences that are certainly controlled by bulk composition, the strange poikiloblastic and "enigmatic" garnets point to a common process that is seemingly acting not only locally on the granulites of Sankt Leonhard or on those of the Dunkelsteiner Wald, but on a regional scale. As in the case of the GRT-type Z3 above, the suspicion falls again on the metasomatic agents related with anatectic melts and/or associated fluids. The anatectic nature of at least the quartzo-feldspathic rocks in the Gföhl Nappe System and Drosendorf Nappe System has been inferred by Petrakakis $(1986,1997)$, Racek et al. (2006), Hasalová et al. (2008a), Schulmann et al. (2008) and references therein. Metasomatic alteration mechanisms affecting minerals and rocks by anatectic melts and/or fluids seem to be complex and are currently not clear. However, as far as the poikiloblastic garnets of this study are considered, it should be recalled (see Fig. 9) that they predate the formation of the crack symplectites. Their formation is, therefore, related most probably to the activity of metasomatizing agents during the latest stage of garnet evolution.

The inferred more or less isothermal decompression starting in the stability field of the primary assemblage above $11 \mathrm{kbar}$ and ending in that of the crack symplectite at 5$7 \mathrm{kbar}$ (see Fig. 12) constrains also any other symplectite formed by breakdown of the primary assemblage, e.g., also the inclusion-related symplectites not treated here in detail. For the very similar crack and rim symplectites, the relevant reactions took place until the pressure reached values of less than $\sim 7 \mathrm{kbar}$. This decompression was most probably related to the nearly vertical extrusion of the rocks to mid-crustal levels suggested by Štípská et al. (2004), Schulmann et al. (2005, 2008), Franěk et al. (2006), Tajčmanová et al. (2006), Racek et al. (2006) and Duretz et al. (2011). This major deformation event was most likely responsible also for the development of subgrains within GRT-type Z1 (see Fig. 8), and the opening of cracks within garnet (Fig. 4e) and rock matrix (Fig. 2a). We interpret the straight, darker, hornblende-rich and white mica-rich bands cross-cutting the rock matrix as cracks that were healed during late, post-decompression recrystallization conditions (see below). At the high temperatures indicated by the metamorphic assemblages of the sample at hand, the opening of such brittle structures implies rather high strain rates. The cracks in garnet and rock matrix have enabled fluid infiltration and favored component mobility to sites of interface reaction forming the symplectites.

On the other hand, the excellent preservation of the delicate symplectite microstructures, especially of the "unprotected" rim kelyphites, points to symplectite formation under low differential stress. This is supported also by the extensive matrix recrystallization leading to the observed granoblastic matrix as well as by the complete absence of localized shearing even along favorable preexisting, brittle planar elements like the healed cracks shown in Fig. 2a (see Mancktelow, 2008; Mancktelow and Pennacchioni, 2013). The crack symplectites were formed largely at post-decompression conditions during isobaric cooling at $\sim 6 \mathrm{kbar}$ (see Fig. 12). As discussed in Sect. 8.1, symplectite formation during cooling is indicated by the micro-structural features shown by the symplectitic phases. Isothermal decompression of the Gföhl Nappe System followed by isobaric cooling at similar pressures has been demonstrated also in GRT + OPX granulites (Petrakakis and Jawecki, 1995; Petrakakis, 1997). This stage of the rock evolution is likely related to the lateral distribution of the rocks by horizontal channel flow within the middle crust, as suggested by the authors cited in the previous paragraph.

It has been argued by Remmert et al. (2018) that symplectite formation only occurs in a rather narrow window of bulk water contents. Whereas the formation of symplectites is hampered in completely dry systems, a Garben microstructure with little spatial organization is formed at high water contents. The presence of a fluid phase during formation of the crack symplectites is corroborated by the fact that within the crack symplectites, which are largely isochemical with GRT-type C, the plagioclase contains Na (see Fig. 10 and Supplement, Table S5). This Na could not have been derived from the precursor garnet, but was rather necessarily supplied from the environment. It is very likely that at least some $\mathrm{Na}$ (and $\mathrm{Si}$ ) was transferred to the reaction front, and some $\mathrm{Ca}$ (and $\mathrm{Al}$ ) in the opposite direction. The latter possibly contributed to the an enrichment of the outer rims of matrix plagioclase (see Figs. 2c, 4a and b). The transfer of the chemical components most likely occurred by diffusion through fluid films at the grain boundaries and along triple junction arrays in the rock matrix. Furthermore, small volumes of $\mathrm{HBL}+\mathrm{PL}$ symplectite evolving from OPX + SP + PL symplectite during the latest stages of kelyphite evolution provide additional direct evidence for the presence of a hydrous fluid. The observed slope inversion of the diffusion profile shown in Fig. 5d most likely reflects this change of the symplectitic assemblage. At least part of the fluid mediating symplectite formation at post-decompression conditions may have been derived by the crystallization of anatectic melts. In this respect, the cracks in the rock matrix might have promoted fluid mobility by forming favorable pathways to reaction sites.

Despite the cooling documented by the symplectite microstructures, symplectite formation led to very limited re- 
placement of the garnet. This is also supported by the remarkably very short duration of symplectite formation calculated from the diffusion profile shown in Fig. 5e. Furthermore, the recrystallized matrix currently contains a hightemperature, barely retrogressed assemblage with abundant clinopyroxene and plagioclase and very minor hornblende. These features are consistent with limited availability of $\mathrm{H}_{2} \mathrm{O}$ rather than increasingly sluggish reaction kinetics induced by cooling. The reason for this might have been the healing of the rock cracks due to the enhanced local formation of hornblende and white mica.

Finally, the following question deserves some discussion. If metasomatic modification of $\mathrm{FeO}, \mathrm{MgO}$ and $\mathrm{CaO}$ in garnet has taken place, how reliable are the presented equilibrium assemblage diagrams that rely on compositions assumed to be closed for such system components? As the metasomatic modification affected at least the garnet, but before decompression, the question applies only to the primary assemblage GRT + CPX + Ky. As discussed, the modification of garnet seems to be minor and of the order of $\sim 12 \mathrm{~mol} \%$ Ca equivalents. On the other hand, what might have been the alternative primary assemblage for this peraluminous, potassium-poor and CPX-rich rock besides GRT $+\mathrm{CPX}+\mathrm{Ky}$ ? Due to the small number of coexisting phases (see Fig. 11a), the high variance of the primary assemblage is related to its large stability field extending far above $15 \mathrm{kbar}$ (see inset in Fig. 11b). This underlines its low sensitivity in terms of changing $P-T$ as well as other external factors like the chemical potentials of $\mathrm{CaO}, \mathrm{FeO}$ and $\mathrm{MgO}$ involved in the metasomatic change of the garnet. These changes may have induced the observed displacements of composition in garnet away from equilibrium, but hardly the assemblage. Therefore, and despite this metasomatic modification, we consider GRT $+\mathrm{CPX}+\mathrm{Ky}$ as the primary assemblage, precluding, however, reliable geobarometric estimates derived from it.

\subsection{Towards more reliable $P-T$ estimates}

Apart from emphasizing the inherent uncertainty in the $P-T$ estimates of rocks within the Gföhl Nappe System, a more general implication of our analysis needs to be addressed. Despite the refractory nature of garnet, its composition may be strongly modified during high-grade metamorphism. The primary composition zoning attained during growth may be partially or completely obliterated by intra-crystalline diffusion during prolonged high-temperature metamorphism and/or during successive stages of recrystallization, partial replacement or diffusion-mediated metasomatic alteration. Chemical alteration of garnet can be directly identified from secondary chemical zoning that is directly related to latestage features such as cracks, veins or resorption features. More cryptic alteration such as homogenization during thermal annealing may be difficult to identify by petrographic means. In such a case, the comparison of observed garnet compositions and calculated garnet composition isopleths in equilibrium assemblage diagrams (pseudo-sections) is the method of choice for testing whether an equilibrium composition was preserved or if the garnet composition is due to post-formational modification. When reconstructing the $P$ $T$ conditions of high-grade metamorphic rocks, such a test is mandatory. Even at conditions where mafic granulites are well below their solidus temperature, anatectic melt derived from nearby felsic granulites may serve as a metasomatic agent that facilitates chemical mass transport and, at the same time, speeds up mineral reactions. Typically, in the case of Gföhl Nappe System within the Moldanubian Unit, mafic granulites are comparatively small rock bodies immersed in more voluminous felsic granulites. Interaction between felsic and mafic lithologies at granulite facies conditions is an efficient and widespread process leading to partial loss of the "petrogenetic memory" of otherwise refractory minerals and rock types.

\section{Conclusions}

- Peraluminous, mafic granulites associated with the ultramafic rocks of the Dunkelsteiner Wald in the Gföhl Nappe System, Austria, contain large garnets embedded in a well-recrystallized granoblastic matrix of clinopyroxene, plagioclase and minor hornblende. The garnets contain inclusions of kyanite and Al-rich, Na-poor clinopyroxene. They are partly replaced by (a) symplectites around Ky inclusions composed of Crn, SPR, SPL, PL, (b) symplectites at their rims comprising OPX, SPL, PL and minor HBL and (c) symplectites within cracks containing OPX, CPX, SPL, PL and minor HBL. The diversity of these symplectites is locally controlled.

- Extensive microprobe analysis and element mapping revealed that the garnets are $\mathrm{Ca}$ and $\mathrm{Mg}$ rich and compositionally complex. They are composed of different composition patterns (GRT-types) showing a specific relation among Fe, Mg and Ca. These GRT-types can be repeatedly observed in garnets. The mode of occurrence and the cross-cutting relations among these GRT-types within large garnet crystals allowed for the derivation of their relative timing of formation. At least the latest GRT-types show strong evidence of metasomatic alteration. Related with these garnet types are peculiar poikiloblastic garnets with numerous plagioclase inclusions.

- Crack symplectites are shown to be largely isochemical with the oldest garnet type hosting them.

- Garnet in contact with symplectites shows a pronounced, diffusion-driven composition change within a few dozen micrometers ahead the garnet-symplectite interface. This change is linked to symplectite formation and has overprinted the underlying GRT-types. Therefore, symplectite formation post-dates the bulk compositional structure of garnet. 
- Calculated equilibrium assemblage diagrams and analysis of the measured garnet component isopleths showed the following: (a) the primary assemblage GRT $+\mathrm{Al}-$ rich $\mathrm{CPX}+\mathrm{Ky}$ was formed at pressures above $11 \mathrm{kbar}$ and temperatures about $800^{\circ} \mathrm{C}$; (b) ) none of the measured compositions in all GRT-types is a preserved equilibrium composition; (c) especially the most Ca-rich GRT-types show metasomatically induced loss of Fe and $\mathrm{Mg}$, which affected their $\mathrm{Ca}$ content. This alteration took place at $P-T$ conditions close to the stability conditions of the primary assemblage; (d) the crack symplectite assemblage is stable at pressures of 5-7 kbar and temperatures above $\sim 730^{\circ} \mathrm{C}$.

- Calculation of equilibrium assemblage diagrams (pseudo-sections) allows for the evaluation of the equilibrium or non-equilibrium state of minerals, particularly of garnet, which is commonly included in calculations of $P-T$ estimates. With these techniques, the observed mineral assemblages and measured mineral compositions can be reproduced, adding to the reliability and confidence of the thus derived $P-T$ estimates and $P-T$ paths.

- At least for metamorphic conditions pertaining to highgrade Moldanubian rocks, the commonly made assumption that measured $\mathrm{Ca}$ contents and $\mathrm{Ca}$ zoning in garnet invariably preserves past $P-T$ information is called into question.

- The rocks underwent more or less isothermal decompression to pressures between 5 and $7 \mathrm{kbar}$ related to the extrusion of the rocks of the Gföhl Nappe System to middle crustal levels. This major deformation event led to the formation of subgrains in garnet as well as cracks in garnet and rock matrix.

- The decompression induced the formation of the symplectites. At least the crack and rim symplectites were formed after decompression within a short time interval of less than $0.5 \mathrm{ka}$ during almost isobaric cooling at $\sim 6 \mathrm{kbar}$ under conditions of low differential stress. Symplectite formation was promoted by hydrous fluids.

- The limited extent of garnet replacement by symplectites, the very short time interval of symplectite formation and the preservation of a barely retrogressed, granoblastic rock matrix of clinopyroxene, plagioclase and minor hornblende indicate limited availability of $\mathrm{H}_{2} \mathrm{O}$ during cooling of the rocks.

Data availability. All underlying data are available in the Supplement.

\section{The Supplement related to this article is available online at https://doi.org/10.5194/se-9-797-2018-supplement.}

Competing interests. The authors declare that they have no conflict of interest.

Acknowledgements. Theo Ntaflos (Department of Lithospheric Research, University of Vienna) is acknowledged for providing the samples many years ago. Franz Kiraly is acknowledged for provision of technical expertise and assistance during microprobe work. Ben Huet and Christoph Iglseder (Geological Survey of Austria) contributed to the goals of this paper with provision of geological maps, critical comments and fruitful discussions. Bernhard Grasemann (Department of Geodynamics and Sedimentology, University of Vienna) is acknowledged for critical reading and commenting of the first draft of the manuscript. Hans-Joachim Massonne (Universität Stuttgart) and Martin Racek (Institute of Petrology and Structural Geology, Faculty of Science, Charles University, Prague) are acknowledged for thorough and constructive review of the paper. The editorial work of Frederico Rossetti is acknowledged for essential contributions to shaping of the paper and sharpening of the outcomes.

Edited by: Federico Rossetti

Reviewed by: Martin Racek and Hans-Joachim Massonne

\section{References}

Carswell, D. A., Möller, C., and O'Brien, P. J.: Origin of sapphirineplagioclase symplectites in metabasites from Mitterbachgraben, Dunkesteinerwald granulite complex, Lower Austria, Eur. J. Mineral., 1, 455-466, 1989.

Cháb, J., Stráník, Z., and Eliáš, M.: Geologická mapa Čské republiky 1: 500 000, Čská geologická služba, Praha, Czech Republic, 2007.

de Capitani, C. and Petrakakis, K.: The computation of equilibrium assemblage diagrams with Theriak/Domino software, Am. Mineral., 95, 1006-1016, 2010.

Chakraborty, S. and Ganguly, J.: Cation diffusion in alumosilicate garnets: experimental determination in spessartine-almandine diffusion couples, evaluation of effective binary diffusion coefficients, and applications, Contrib. Mineral. Petr., 111, 74-86, 1992.

Duretz, T., Kaus, B., Schulmann, K., Gapais, D., and Kermarrec, J.: Indentation as an extrusion mechanism of lower crustal rocks: Insight from analogue and numerical modelling, application to the Eastern Bohemian Massif, Lithos, 124, 158-168, 2011.

Faryad, S., W., Nahodilová, R., and Dolejš, D.: Incipient eclogite facies metamorphism in the Moldanubian granulites revealed by mineral inclusions in garnet, Lithos, 114, 54-69, 2010.

Franěk, J., Schulmann, K., and Lexa, O.: Kinematic and rheological model of exhumation of high-pressure granulites in the Variscan orogenic root: example of the Blanský les granulite, Bohemian Massif, Czech Republic, Miner. Petrol., 86, 253-276, 2006. 
Gaidies, F., Milke, R., Heinrich, W., and Abart, R.: Metamorphic mineral reactions, European Mineralogical Union and the Mineralogical Society of Great Britain and Ireland, EMU Notes in Mineralogy, Jena, Germany, vol. 16, 469-540, 2017.

Hasalová, P., Janoušek, V., Schulmann, K., Štípská, P., and Erban, V.: From orthogneiss to migmatite: geochemical assessment of the melt infiltration model in the Gföhl Unit Moldanubian Zone, Bohemian Massif, Lithos, 102, 508-537, 2008a.

Hasalová, P., Štípská, P., Powell, R., Schulmann, K., Janoušek, V., and Lexa, O.: Transforming mylonitic metagranite by opensystem interactions during melt flow, J. Metamorph. Geol., 26, 55-80, 2008b.

Jedlička, R., Faryad, S., and Hauzenberger, C.: Prograde metamorphic history of UHP granulites from the Moldanubian Zone Bohemian Massif revealed by major element and Y+REE zoning in garnets, J. Petrol., 56, 2069-2088, 2015.

Jedlička, R. and Faryad, S. W.: Felsic granulite with layers of eclogite facies rocks in the Bohemian Massif; did they share a common metamorphic history?, Lithos, 286-287, 408-425, 2017.

Johansson, L. and Möller, C.: Formation of sapphirine during retrogression of a basic high-pressure granulite, Roan, Western Gneiss Region, Norway, Contrib. Mineral. Petr., 94, 29-41, 1986.

Kalvoda, J., Bábek, O., Fatka, O., Leichmann, J., Melichar, R., Nehyba, S., and Spacek, P.: Brunovistulian terrane (Bohemian Massif, Central Europe) from late Proterozoic to late Paleozoic: A review, Int. J. Earth Sci., 97, 497-518, 2008.

Kleinschrodt, R. and Duyster, J.: HT-deformation of garnet: An EBSD study on granulites from Sri Lanka, India and Ivrea Zone, J. Struct. Geol., 29, 1829-1844, 2002.

Kleinschrodt, R. and McGrew, A.: Garnet plasticity in the lower continental crust: Implications for deformation mechanisms based on microstructures and SEM-electron channeling pattern analysis, J. Struct. Geol., 22, 795-805, 2000.

Kornprobst, J., Piboule, M., Roden, M., and Tabit, A.: Corundumbearing Garnet Clinopyroxenites at Beni Bousera Marocco: Original plagioclase-rich gabbros recrystallized at depth within the Mantle?, J. Petrol., 31, 717-745, 1990.

Krenmayr, H., Schnabel, W., and Reitner, J.: Geologische Karte von Oberösterreich 1:200000, Geologische Bundesanstalt, Wien, Austria, 2006.

Linner, M.: Metamorphism and partial melting of paragneisses of the Monotonous Group, SE Moldanubicum, Austria, Miner. Petrol., 58, 215-234, 1996.

Mancktelow, N. S.: Interaction between brittle fracture and ductile flow during crustal deformation, Boll. Soc. Geol. It. (Ital. J. Geosci.), 127, 217-220, 2008.

Mancktelow, N. S. and Pennacchioni, G.: Late magmatic healed fractures in granitoids and their influence on subsequent solidstate deformation, J. Struct. Geol., 57, 81-96, 2013.

Medaris, L., Wang, H., Jelínek, E., Mihaljevič, M., and Jakeš, P.: Characteristics and origins of diverse Variscan peridotites in the Gföhl Nappe, Bohemian Massif, Czech Republic, Lithos, 82, 123, 2005.

Obata, M.: Kelyphite and symplectite: textural and mineralogical diversities and universality, and a new dynamic view of their structural formation, in: New Frontiers in Tectonic Research General Problems, Sedimentary Basins and Island Arcs, edited by: Sharkov, E. V., chap. 05, InTech, Rijeka, Croatia, 2011.
Obata, M. and Ozawa, K.: Topotaxic relationships between spinel and pyroxene in kelyphite after garnet in mantle-derived peridotites and their implications to reaction mechanism and kinetics, Miner. Petrol., 101, 217-224, 2011.

O'Brien, P. J.: Challenges in high-pressure granulite metamorphism in the era of pseudosections: reaction textures, compositional zoning and tectonic interpretation with examples from the Bohemian Massif, J. Metamorph. Geol., 26, 235-251, 2008.

Petrakakis, K.: Metamorphism of high-grade gneisses from the Moldanubian zone, Austria, with particular reference to the garnets, J. Metamorph. Geol., 4, 323-344, 1986.

Petrakakis, K.: Evolution of Moldanubian rocks in Austria: review and synthesis, J. Metamorph. Geol., 15, 203-222, 1997.

Petrakakis, K. and Jawecki, C.: High-grade metamorphism and cooling evolution of Moldanubian granulites, Eur. J. Mineral., 7, 1183-1203, 1995.

Racek, M., Štípská, P., Pitra, P., Schulmann, K., and Lexa, O.: Metamorphic record of burial and exhumation of orogenic lower and middle crust: a new tectonothermal model for the Drosendorf window Bohemian Massif, Austria, Miner. Petrol., 86, 221-251, 2006.

Racek, M., Štípská, P., and Powell, R.: Garnet-clinopyroxene intermediate granulites in the St. Leonhard massif of the Bohemian Massif: ultrahigh-temperature metamorphism at high pressure or not?, J. Metamorph. Geol., 26, 253-271, 2008.

Remmert, P., Heinrich, W., Wunder, B., Morales, L., Wirth, R., Rhede, D., and Abart, R.: Synthesis of monticellite-forsterite and merwinite-forsterite symplectites in the $\mathrm{CaO}-\mathrm{MgO}-\mathrm{SiO}_{2}$ model system: influence of temperature and water content on microstructure evolution, Contrib. Mineral. Petr., 173, 1-17, 2018.

Schnabel, W.: Geologische Karte von Niederösterreich 1 : 200000 , Geologische Bundesanstalt, Vienna, Austria, 2002.

Schulmann, K., Kröner, A., and Hegner, E. E. A.: Chronological constraints on the pre-orogenic history, burial and exhumation of deep-seated rocks along the eastern margin of the Variscan orogen, Bohemian Massif, Czech Republic, Am. J. Sci., 305, 407448, 2005.

Schulmann, K., Lexa, O., Štípská, P., Racek, M., Tajčmanová, L., Konopásek, J., Edel, J., Peschler, A., and Lehmann, J.: Vertical extrusion and horizontal channel flow of orogenic lower crust: key exhumation mechanisms in large hot orogens?, J. Metamorph. Geol., 26, 273-297, 2008.

Štípská, P. and Powell, R.: Constraining the $P-T$ path of a MORBtype eclogite using pseudosections, garnet zoning and garnetclinopyroxene thermometry: an example from the Bohemian Massif, J. Metamorph. Geol., 23, 725-743, 2005a.

Štípská, P. and Powell, R.: Does ternary feldspar constrain the metamorphic conditions of high-grade meta-igneous rocks? Evidence from orthopyroxene granulites, Bohemian Massif, J. Metamorph. Geol., 23, 627-647, 2005b.

Štípská, P., Schulmann, K., and Kröner, A.: Vertical extrusion and middle crustal spreading of omphacite granulite: a model of synconvergent exhumation Bohemian Massif, Czech Republic., J. Metamorph. Geol., 22, 179-198, 2004.

Štípská, S., Powell, R., and Racek, M.: Rare eclogite-mafic granulite in felsic granulite in Blanský les: precursor of intermediate granulite in the Bohemian Massif?, J. Metamorph. Geol., 32, 325-345, 2014a. 
Štípská, S., Powell, R., Racek, M., and Lexa, O.: Intermediate granulite produced by transformation of eclogite at a felsic granulite contact, in Blanský les, Bohemian Massif, J. Metamorph. Geol., 32, 347-370, 2014b.

Svojtka, M., Ackerman, L., Medaris, L., G., Hegner, E., Valley, J., W., Hirajima, T., Jelínek, E., and Hrstka, T.: Petrological, Geochemical and $\mathrm{Sr}-\mathrm{Nd}-\mathrm{O}$ Isotopic Constraints on the Origin of Garnet and Spinel Pyroxenites from the Moldanubian Zone of the Bohemian Massif, J. Petrol., 57, 897-920, 2016.
Tajčmanová, L., Konopásek, J., and Schulmann, K.: Thermal evolution of the orogenic lower crust during exhumation within a thickened Moldanubian root of the Variscan belt of Central Europe, J. Metamorph. Geol., 24, 119-134, 2006.

Vrána, S., Janoušek, V., and Franěk, J.: Contrasting mafic to felsic HP-HT granulites of the Blanský les Massif Moldanubian Zone of southern Bohemia: complexity of mineral assemblages and metamorphic reactions, J. Geosci., 58, 347-378, 2013. 